\title{
The East Papuan Languages: A Preliminary Typological Appraisal
}

\author{
Michael Dunn; Ger Reesink; Angela Terrill
}

Oceanic Linguistics, Vol. 41, No. 1. (Jun., 2002), pp. 28-62.

Stable URL:

http://links.jstor.org/sici?sici=0029-8115\%28200206\%2941\%3A1\%3C28\%3ATEPLAP\%3E2.0.CO\%3B2-\%23

Oceanic Linguistics is currently published by University of Hawai'i Press.

Your use of the JSTOR archive indicates your acceptance of JSTOR's Terms and Conditions of Use, available at

http://www.jstor.org/about/terms.html. JSTOR's Terms and Conditions of Use provides, in part, that unless you have obtained prior permission, you may not download an entire issue of a journal or multiple copies of articles, and you may use content in the JSTOR archive only for your personal, non-commercial use.

Please contact the publisher regarding any further use of this work. Publisher contact information may be obtained at http://www.jstor.org/journals/uhp.html.

Each copy of any part of a JSTOR transmission must contain the same copyright notice that appears on the screen or printed page of such transmission.

The JSTOR Archive is a trusted digital repository providing for long-term preservation and access to leading academic journals and scholarly literature from around the world. The Archive is supported by libraries, scholarly societies, publishers, and foundations. It is an initiative of JSTOR, a not-for-profit organization with a mission to help the scholarly community take advantage of advances in technology. For more information regarding JSTOR, please contact support@ jstor.org. 


\title{
The East Papuan Languages: A Preliminary Typological Appraisal
}

\author{
Michael Dunn
}

MAX PLANCK INSTITUTE FOR PSYCHOLINGUISTICS, NIJMEGEN

\author{
Ger Reesink
}

UNIVERSITY OF LEIDEN

AND MAX PLANCK INSTITUTE FOR PSYCHOLINGUISTICS, NIJMEGEN

\author{
Angela Terrill
}

\author{
AUSTRALIA NATIONAL UNIVERSITY
}

\begin{abstract}
This paper examines the Papuan languages of Island Melanesia, with a view to considering their typological similarities and differences. The East Papuan languages are thought to be the descendants of the languages spoken by the original inhabitants of Island Melanesia, who arrived in the area up to 50,000 years ago. The Oceanic Austronesian languages are thought to have come into the area with the Lapita peoples 3,500 years ago. With this historical backdrop in view, our paper seeks to investigate the linguistic relationships between the scattered Papuan languages of Island Melanesia. To do this, we survey various structural features, including syntactic patterns such as constituent order in clauses and noun phrases and other features of clause structure, paradigmatic structures of pronouns, and the structure of verbal morphology. In particular, we seek to discern similarities between the languages that might call for closer investigation, with a view to establishing genetic relatedness between some or all of the languages. In addition, in examining structural relationships between languages, we aim to discover whether it is possible to distinguish between original Papuan elements and diffused Austronesian elements of these languages. As this is a vast task, our paper aims merely to lay the groundwork for investigation into these and related questions.
\end{abstract}

1. INTRODUCTION. ${ }^{\text {I }}$ The first human occupation of New Guinea is generally assumed to date back to around 50,000 years ago. The earliest dates recorded for Island Melanesia (see map I) range from 29,000 to more than 35,000 years ago

I. We would like to thank the following people for kindly giving us permission to cite unpublished work: Chiyoko Hashimoto, Tanya Laycock, Stephen Levinson, Stellan Lindrud, Eva Lindström, Kazuko Obata, Jim and Diana Parker, Malcolm Ross, Doug and Carolyn Tharp, and Tatsuya Yanagida. We are grateful to John Lynch and one anonymous reviewer for helpful comments on this paper, and to the Max Planck Institute for Psycholinguistics, Nijmegen, and the Max Planck Institute for Evolutionary Anthropology, Leipzig, for supporting this work. 
(see for example Spriggs [1997] for a summary of the various archaeological findings). Much later, around 3,500 years ago, Austronesian speakers arrived in the Bismarck Archipelago from where they rapidly colonized the Pacific islands further to the east and south (Ross I988; Kirch I997).

Now we find a great number of Austronesian languages of the Oceanic subgroup throughout Island Melanesia and, scattered among them, 25 languages that as a group are referred to as the East Papuan languages. Although the time-depth from the earliest settlers to the present is forbidding, it seems reasonable to assume that the present Papuan languages are remote descendants of the languages spoken before the Austronesians came on the scene. One of the first bold hypotheses to link all Papuan languages together is found in Greenberg (I97I). Wurm (I975, I982b), only slightly less daring, proposed that at least all East Papuan languages could be brought together in a single phylum that is divided over three main groupings that are further differentiated into a number of stocks and lower-level families, as in figure I.

Although there are lexical correspondences that allow lower-level groupings for some of the proposed families, the higher-level relationships are motivated by some agreements in the pronominal systems and typological and structural similarities. Foley (I986), among others, deferred the possible genetic linking of all Papuan languages until more evidence would come available for proposed smaller groupings, such as the South Bougainville family, which he considered probably related to the North Bougainville family.

More recently, Ross (2000) concludes that the pronominal evidence does not support Wurm's "East Papuan" phylum, nor some of the larger groups that Wurm proposed. He finds support for some of the smaller groupings of some families, such as West New Britain (possibly including Yélî Dnye), East New Britain, two families on Bougainville (North and South), and a Central Solomons family. His classification is plotted against Wurm's in figure $\mathrm{I}$.

The fact that just about all of the East Papuan languages, except Sulka on New Britain and Yélî Dnye on Rossel, make a gender distinction somewhere in the pronominal systems may point to some shared feature from before the time of contact with Austronesian speakers. As Ross (2000) warns, this does not immediately prove a single ancestor, because gender can be diffused by contact, as seen, for example, in some Austronesian languages in West New Britain (Chowning I996:57). Other influences between non-Austronesian and Austronesian languages in this area have been reported by various scholars, for example, Thurston (I982), Tryon (I994), and Wurm (I982a). Terrill (2002) examines the typological and historical significance of gender systems in the East Papuan languages; we do not pursue this topic further here.

It seems worthwhile to investigate which features are shared by the rather heterogeneous East Papuan languages, and to what extent. Is it possible to distinguish between inherited elements and those that have been diffused before or during the time of contact with Austronesians? Can we formulate what is typically Papuan about these languages? Could it be that some traits associated with the Oceanic subgroup of Austronesian can be traced to the older Papuan languages of Island Melanesia, just as 


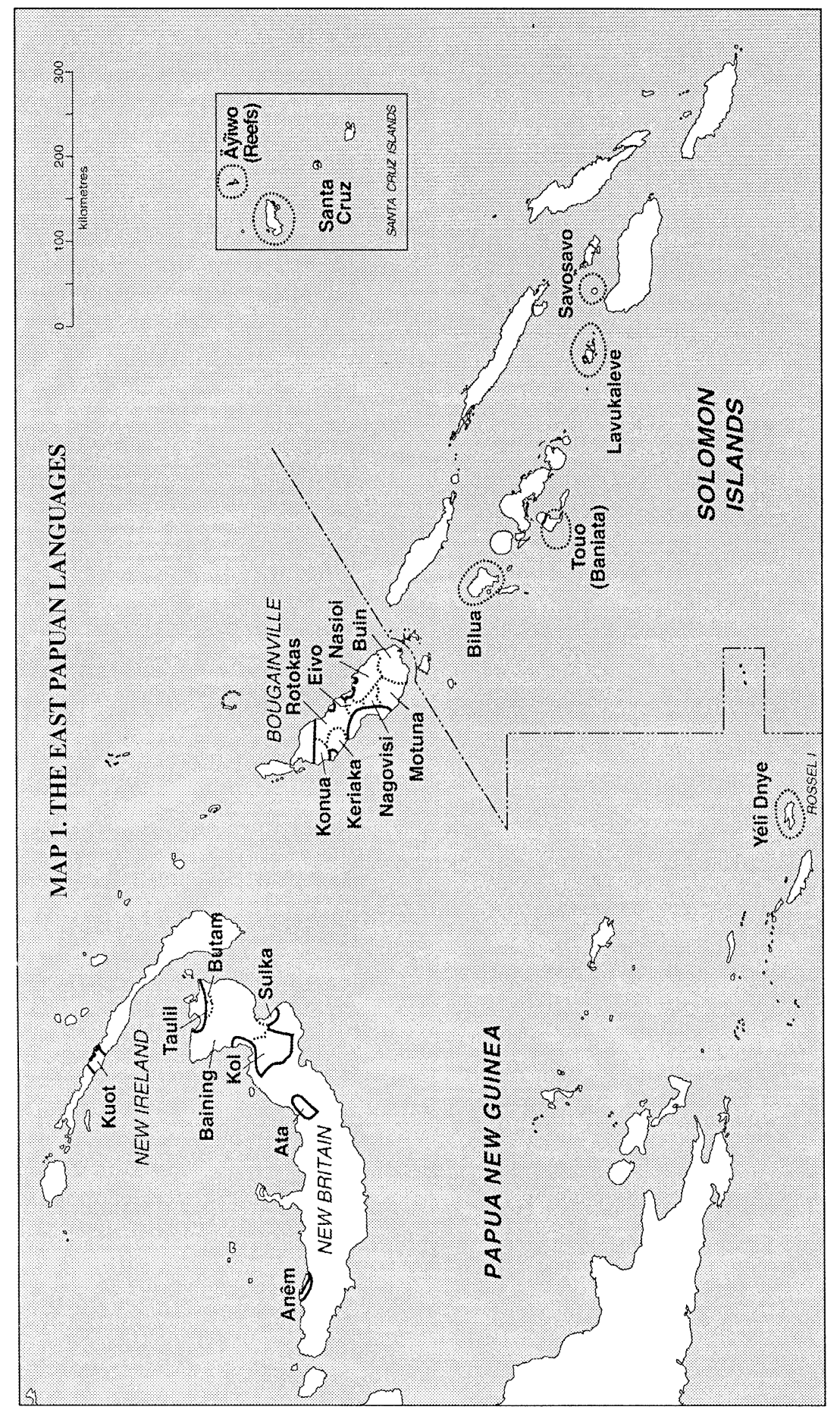


FIGURE 1. COMPARISON OF WURM'S (1982b) AND ROSS'S (2000) GENETIC GROUPINGS OF EAST PAPUAN LANGUAGES

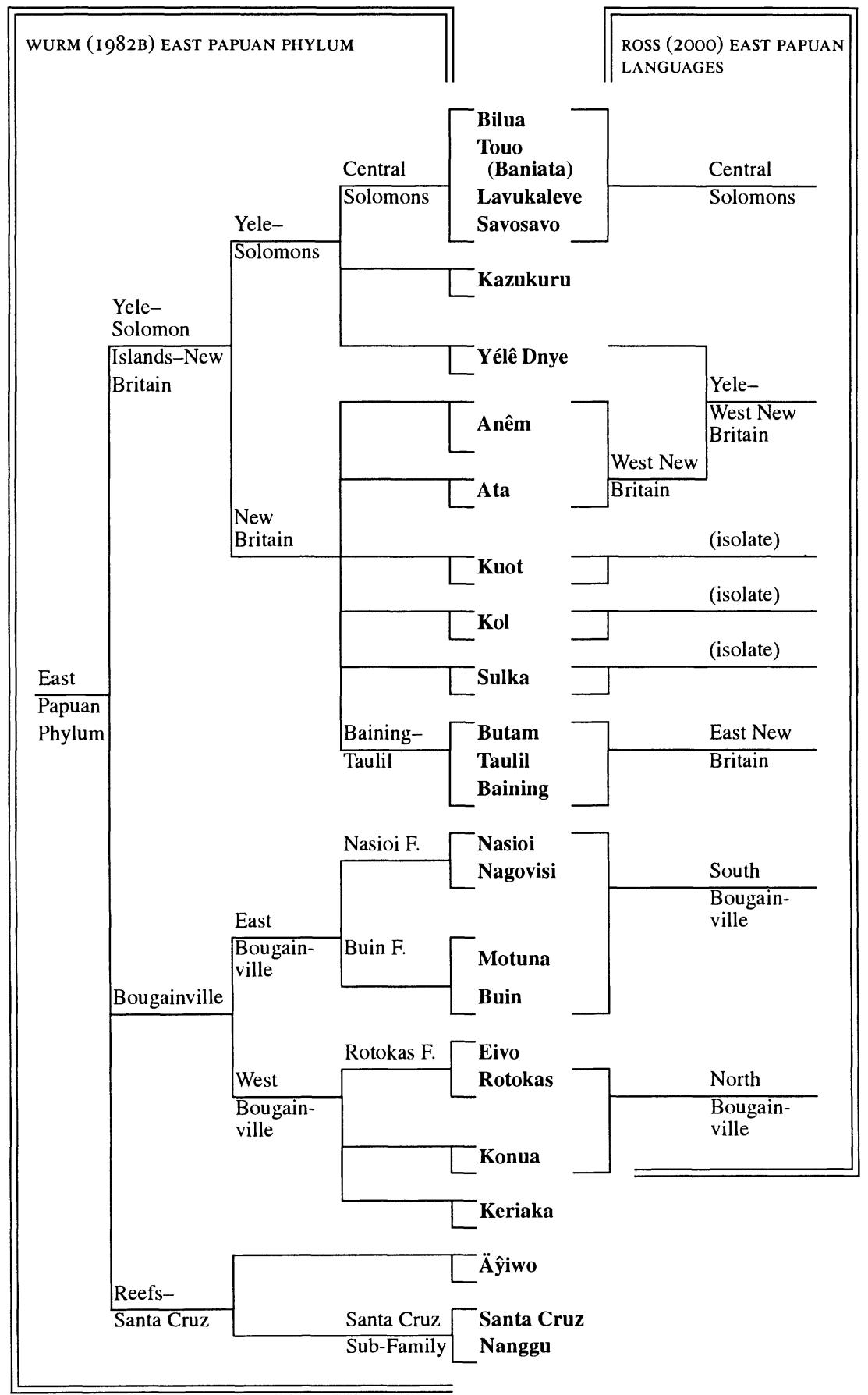


some human genetic markers of Melanesians and Polynesians point to a mixing of Austronesian immigrants and the original Papuan populations (Kayser et al. 2000)? To what extent have typically Austronesian traits been adopted into Papuan languages?

Despite the fact that, for some East Papuan languages, detailed descriptions are available, it is far too early to even attempt a preliminary answer to these questions, because for many languages relevant data are not (yet) available. Thus, our goals are far more modest. In order to make a beginning with an in-depth analysis and comparison of various linguistic items that are spread over the East Papuan languages, we present (in section 2) a survey of the word orders of clause and noun phrase, and other features of clause structure; in section 3 a survey of the types of pronominal systems with their morphological realizations, and in section 4 an overview of some of the bound verbal morphology. Discussion and conclusions appear in section 5 .

We make occasional comparative notes, highlighting similarity or difference with either Oceanic languages or Papuan languages of the mainland, in particular those considered to make up the Trans-New Guinea Phylum (TNGP). In general, we follow the east-west, north-south axis as we discuss the various languages. In the conclusion, we discuss the typological relationships of these languages with respect to their possible genetic relationship with the languages of mainland Papua New Guinea, as well as with each other.

\section{SYNTACTIC PATTERNS}

2.1 WORD ORDER IN THE CLAUSE. Most East Papuan languages exhibit the "normal" constituent order of Papuan languages, which is verb-final, with a relatively free order of nominal constituents. Thus, all the Papuan languages spoken on Bougainville, the Solomon Islands (with the exception of Bilua), and Rossel have this clause structure. The Papuan languages spoken on New Britain all have an SVO order.

Kuot, on New Ireland, forms an exception in that it has a VSO order. It is perhaps no accident that a few Papuan languages on New Britain that are claimed to originate from New Ireland, such as Taulil and Butam, have a V-initial order for "stative" clauses. This also holds for other Papuan languages on or near the Gazelle Peninsula, like Baining and $\mathrm{Kol}$. To what extent these languages employ a syntactic ergative system cannot be determined on the basis of the sketchy information. Consider the examples from Taulil (Laufer I950:636) in (I-2).

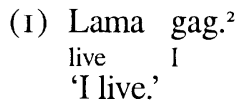
(2) Ta tinak gun.
they ask I.DU
'They ask the two of us.'

Parker and Parker (1977:36) mention that a few stative verbs always precede the predicate person marker. Whether this concerns just a few "experiential verbs" or is indicative of some (split) ergative alignment is not clear.
(3) Arem uut.
sorry I.PL
(4) Uis ta.
'We are sorry.'
cold they
'They are cold.' 
Perhaps significant in connection with these facts of constituent order is the sentence-initial position of the negative adverb (see 2.7).

2.2 ADPOSITIONS. Concomitant to the VO order, we find the use of prepositions rather than postpositions. Thus, prepositions are found in the languages of New Britain, which are all SVO, in VSO Kuot of New Ireland, and in Reefs-Santa Cruz languages, which are predominantly SVO, with VSO occasionally occurring as well.

Postpositions are found in the languages with V-final word order, except Motuna on Bougainville, which has case suffixes to indicate the role of nominal constituents in relation to the predicate. Case is never realized by prefixing anyway, and, in view of the proposal that postpositions may be either free or bound morphemes (Hawkins and Cutler 1988:293; 3 I I ), Motuna could be classified as an SOV + postposition language.

Thus, the correlations between clausal word order and adpositions found in East Papuan languages are not surprising. They agree with the patterns found around the world. There is one exception. Bilua clearly has postpositions, but the word order is SVO, which suggests that the word order may be a more recent development.

2.3 POSSESSIVE NOUN PHRASES. Virtually all East Papuan languages exhibit the Possessor-Possessed order typical of mainland Papuan. At the geographic extremes of the East Papuan area, where indeed more Austronesian influence seems to have been at work, the Austronesian order Possessed-Possessor is found, either as the only order or as an alternative. Thus, VSO Kuot of New Ireland has POS'D + POS'R, as do the languages of Reefs-Santa Cruz.

In Anêm and Ata, nouns belong to various classes depending on the form of the possessor suffix they take, as in Anêm tita-n-ai 'father-CL-ISG' and nan- $u-i$ 'garden-CL-ISG' . ${ }^{3}$ For Anêm Noun + Noun possession, according to Thurston (I982:40-4I), both orders of POS'R + POS'D and POS'D + POS'R are available. In both cases, the POS'D is suffixed. The latter order conveys that the POS'R is a modifier. Thurston says (40) that it behaves syntactically as a unit, by which he apparently means "like a compound," and presumably the POS'R noun is generic.

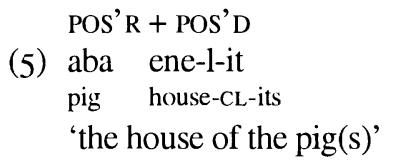

(6) ene-il aba
house-its pig
'a pig house'

2. For each language, the orthography used in the original source is retained. Glosses are retained as nearly as possible, too, while conforming with this journal's style for abbreviations. As identical glosses may have different meanings in different languages, readers are urged to refer to the cited sources. The following abbreviations are used: A, adjective; ACT, action particle; ANT, anterior; ART, article; ATTR, attributive; BEN, benefactive; $\mathrm{CL}$, class marker; COMIT, comitative; CONT, continuative; DEF, definite; DEM, demonstrative; DIM, diminutive; DIST, distal; DU, dual; EXCL, exclusive; EMPH, emphatic; ERG, ergative; F, feminine; FOC, focus; FUT, future; HAB, habitual; INCL, inclusive; INDEF, indefinite; INDIC, indicative; IRR, irrealis; LINK, linking affix; M, masculine; MED, medial; N, neuter; NEG, negative; NF, nonfinite; NH, nonhuman; NUM, numeral; O, object; PERF, perfective; PL, plural; PRPN, proper noun marker; POSS, possession; PROG, progressive; PROX, proximal; PUNCT, punctiliar; S, subject; SG, singular; SBD, subordinate; $\mathrm{STM}_{2}$, 2nd element of discontinuous stem; TRANS, transitive.

3. The morphemes glossed here and below as noun class markers (CL) are not glossed in the original source, but their function is clear from Thurston (1982:87), for example. 
The possessor in the first position may be definite and specific, modified with A or Dem, and so forth, forming a separate NP, as in (7).

(7) an klan lan ki-l-o ombomba tree DIM that leaf-its big

'the big leaves of that dear little tree'

In East New Britain languages, the pronominal possessor is prefixed to the possessed noun, and the order for nominal possession is likewise the canonical Papuan POS'R + POS'D, as in Sulka:

(8) ko-ta-kom

ISG-EMPH-knife

'my own knife' (Tharp I996:80)

(9) e-soma ka-kom ka-rain PRPN-Soma 3SG-knife 3SG-handle

'Soma's knife's handle' (Tharp I996: I I 8)

The data on Kol, Sulka, and Baining do not allow a precise statement on the conditions for different possessive constructions found in these languages. For example, Tharp (I996: I I8) states explicitly that Sulka does not distinguish alienable and inalienable possession, although he distinguishes a set for nonkinship terms and one for kinship terms. But nonkinship terms can also be possessed with a postnominal phrase, as Tharp calls it a Possessive Relative clause (I I7):

(IO) a-kom to mkor dok

SG-knife SG.DIST.DEM POSS ISG

'my knife' (presumably means something like 'that knife which is mine')

The possessive pronouns consisting of nang- + personal pronoun (I996:87) are not illustrated, so it is not possible to compare the three types of possession mentioned here.

The languages of Bougainville, Solomon Islands (except Bilua), and Rossel are SOV (excepting only Bilua) and have for the most part POS'R + POS'D. Buin seems to have the Austronesian order POS'D + POS'R, which in neighboring Motuna is available as alternative order used for comparisons (Onishi 1994:244):

(I I) ong moo ngo-no-mung

DEM.N coconut ISG.POSS-LINK-CL.fruit

'this coconut which I own'

2.4 NOUN PHRASE. There is considerable variation in the order of NP constituents. In this respect, the East Papuan languages resemble the bulk of other Papuan languages, whether they belong to the TNGP or the Sepik-Ramu group, to mention just the largest groups. It is hard to say whether pre- or postnominal adjectives and/or demonstratives are the norm for Papuan languages. Foley (I998:5I4) claims that "modifiers generally precede their head noun," but allows that "many Papuan languages do diverge from this generalization." He also observes that determiners are typically lacking in Papuan languages, in contrast with Austronesian languages.

Therefore, it is remarkable to find an article-like element in a number of the East Papuan languages, like Ata, Sulka, and Baining on New Britain, Motuna and 
Koromira on Bougainville, and Touo (Baniata) and Lavukaleve in the Solomons. ${ }^{4}$ Thurston (1982:25) explicitly mentions that Anêm, which is the most western Papuan language of this area, and neighboring Austronesian language Lusi (the two languages do share a number of features, which is Thurston's main topic) do not have a phrase-marking particle (read: article or noun marker), in contrast, for example, to other Austronesian languages and Papuan Baining. Consider the example from Parker and Parker (1977:39), in which the NP order seems to be DEM-PL + $\mathrm{ART}+$ Head N + ART + A-PL + ART + NUM, suggesting that the article (in one of its three manifestations $a m a \sim a \sim m a$ ) functions as a kind of ligature in the NP:

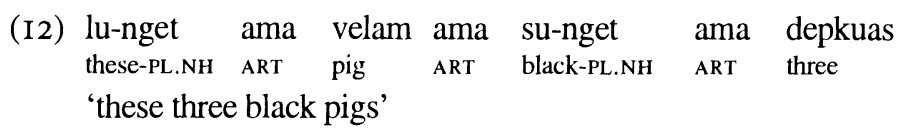

The languages by no means agree with respect to form or function of the article, although in most of these languages, the article is found in prenominal position. In a number of languages, the articles do indicate gender and/or number of the head noun. Here are examples from Ata, Sulka, and Motuna.

ATA (Hashimoto n.d.)

(I3) Ta-ngiala ta-kitu'a la'ia-xa'a misevile. PL-bird PL-small be.angry-3PL.S very

'Small birds are very angry.'

SULKA (Tharp I996: I08)

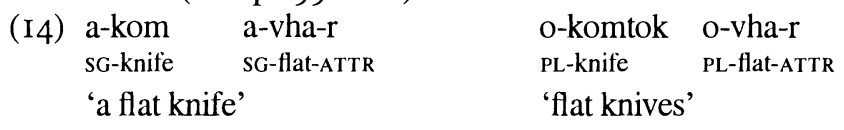

Motuna (Onishi 1994: 138) articles agree in gender with the head noun, and they vary in form according to case- that is, they are suffixed with case markers.
(I5) hoo nomnai
ART.M person/people
'(a/the) person/people'
tii kuraisa
ART.F woman
'(a/the) woman'
(I6) ho-i nomnai
ART.M-ERG person/people
'by the person/people'

tii-nno kuraisa
ART.F-COMIT woman
'with a/the woman'

Lavukaleve of the Solomons has an article, agreeing with the head noun in number and gender, in the final slot of the NP, as illustrated by (I7) (Terrill 1999:83).

\begin{tabular}{llllll} 
(17) & Kui & na & ia-re & \multicolumn{2}{c}{ a-e-kiu-ge } \\
sun(M) & SG.M.ART & be.hot-NF & \multicolumn{3}{c}{ 35G.M.O-SBD-die-ANT } \\
malav & va & suni & kini & lagi-re & lo-v. \\
people(PL) & PL.ART & all & ACT & shelter-NF & finish-PL
\end{tabular}

'The sun was very hot, and the people all went and sheltered (in the shade).'

\footnotetext{
4. The language referred to here as Touo is commonly, although incorrectly, referred to in the literature as Baniata. Baniata is the name of one region in which the language is spoken; speakers do not recognize Baniata as a name for the whole language, preferring instead Touo (Terrill and Dunn 200I fieldnotes; forthcoming).
} 
A few East Papuan languages have prenominal demonstratives: VSO Kuot on New Ireland agrees with SOV Motuna on Bougainville, SVO Bilua on Vella Lavella of the Solomon Islands, and SOV Yélî Dnye on Rossel in having prenominal demonstratives, while the modifying adjective follows the head noun. A few of the SVO languages of New Britain, Anêm, Kol, and Sulka have the order N + A + NUM + DEM, or with NUM and A in reversed order, as in Ata (see [I8]), and this order is also found in SOV Lavukaleve and the SVO Reefs-Santa Cruz languages.

$\begin{array}{llllll}\text { (I8) memee } & \text { mulu vile } & \text { kea } & \text { kitu'a ane } \\ \text { pig } & \text { male } & \text { one } & \text { white } & \begin{array}{l}\text { small } \\ \text { that }\end{array}\end{array}$ 'that one small white male pig'

The cooccurrence of clausal SOV and phrasal N-A-DEM orders is quite stable in many Papuan languages of the mainland. This phrasal order is also found in the "aberrant" SVO groups, the West Papuan and Torricelli languages, while DEM-A$\mathrm{N}$ is mainly found in some Sepik languages and sections of the Highlands. The phrasal order DEM-N-A is, as far as we are aware, found mainly along the south coast of the mainland. Thus it may not be possible to make general claims for Papuan languages with regard to the structure of the noun phrase.

For Oceanic languages, Lynch (I998:I20) makes the generalization that as a rule adjectives and demonstratives are found in postnominal position, while articles precede the head noun: ART-N-A-DEM. A prenominal article is found in all Oceanic languages, except those spoken on the mainland of New Guinea, the islands of Papua, and Vanuatu (Lynch I998: I IO). Most East Papuan articles are prenominal. Only Lavukaleve has postnominal articles.

2.5 CLAUSE CHAINING. A feature quite typical for Papuan languages in general, at least those of the Sepik-Ramu group and the TNGP, is clause chaining, with different verb forms in nonfinal clauses. These are generally seen as dependent verbs, depending on the sentence-final verb for full specification of tense-aspect-mood (TAM) and person-number of the subject. This kind of information packaging seems to be strongly correlated with the SOV order, in that it is totally absent from the Papuan languages with SVO (New Britain languages and Bilua in the Solomons) or VSO order (Kuot on New Ireland). The implication does not hold universally in the reversed direction, as Yélî Dnye, which has SOV, does not employ clause chaining.

2.6 TAIL-HEAD LINKAGE. Possibly related to other typical Papuan features is the phenomenon of tail-head linkage, whereby the last predicate (sometimes with its object or locative constituent) of a sentence is repeated as the start of a new sentence. It occurs particularly in narrative texts and seems closely linked to the structure of clause chaining. It is at least attested in the New Britain languages Ata, Sulka, and Baining, for New Ireland Kuot, Bougainville Motuna, and Solomons Bilua and Lavukaleve. But it is not present in Yélî Dnye, which also lacks clause chaining.

Thus it is found in languages with SOV, SVO, or VSO order. But it is not restricted to Papuan languages. It may be an original Papuan feature, spread to just about all Austronesian languages spoken nearby, including Tok Pisin and Irianese and Moluccan Malay. Further away from the Papuan sphere of influence it does 
not seem to occur. For example, Austronesian languages to the west of Timor do not utilize this strategy of information flow. To what extent it occurs in Oceanic languages away from contact with Papuan we do not know. If it is absent there as well, it could be seen as typically Papuan.

2.7 POSITION OF NEGATIVE ADVERB. The most frequent position of the negative adverb for sentential negation is preceding the predicate. Thus, for Austronesian languages, this is generally $\mathrm{S}$ NEG V O, and for Papuan languages: $\mathrm{S} O \mathrm{O}$ NEG $\mathrm{V}$. A rather unusual order is found in Papuan languages and their Austronesian neighbors at the western extreme of the Papuan area, the Bird's Head peninsula of Irian Jaya and islands around it (Reesink I998). Not only in some SOV languages (North Halmahera and Yawa on Yapen Island in the Cenderawasih Bay), but also in the SVO languages of the Bird's Head, the negative adverb used for sentential negation is strictly confined to sentence-final position. This seems to have spread to all Austronesian languages in the Moluccas and around the Bird's Head. We hypothesize that a sentence-final position of the negative may be a more general feature of Papuan languages. It is found in Dani languages, while in other languages a sentence-final negative is basically another type of negation, requiring some nominalization of the verbal predicate as, for example, in Sentani and Usan (Reesink 2000).

It seems remarkable, and possibly not an accident, that this unusual feature appears in a few of the East Papuan languages: SVO Anêm and Ata on New Britain and SOV Touo (Baniata) and Lavukaleve (as one option) in the Solomons. Related perhaps are the negative verbal suffixes that are sentence-final in Rotokas and Nasioi, because these languages have the SOV constituent order. There are a few Austronesian languages in Island Melanesia that have a sentence-final negative (Mosel I999). All of these may have adopted this feature from Papuan languages. Here are examples from Anêm, with its Austronesian neighbor Lusi operating in the same way, according to Thurston (I982:3I); likewise Touo.

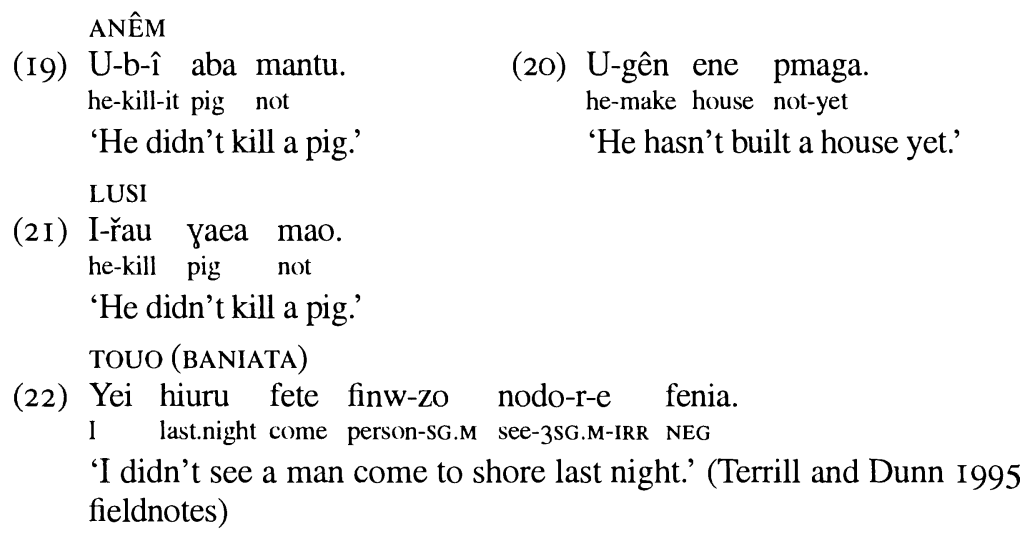

While the negative adverb in VSO Kuot can be placed immediately before any element to be negated, the East New Britain languages seem to have a rather strict clause-inital position for the negator, as in Baining. 
(23) Kuasik ngua mit sa gel ka i ama gelep ngua. not I went to near him because ART shy me 'I didn't go near him because I'm shy.' (Parker and Parker I977:63)

\subsection{SUMMARY OF WORD ORDERS IN EAST PAPUAN LANGUAGES.}

The summary in table I presents the syntactic patterns as found in the East Papuan languages from west to east and north to south. In addition to the order of clause constituents (SVO, VSO, SOV), we indicate the position of the negative adverb (Neg) or whether negation is morphologically marked on the verb (-NEG). Further, information is given whether a language has prepositions (Pr) or postpositions (Po); whether the Possessor precedes the Possessed item (GN) or follows it (NG); what the order of Noun-Adjective-Demonstrative is in the noun phrase, and whether and in what position an additional article (Art) is available. (Note that D stands for Demonstrative, and not for the theoretical entity of Determiner. Whether the question of Determiner Phrase versus Noun Phrase has any relevance in Papuan languages is a matter beyond this survey work.) Items in subscript indicate secondary options of word order. For some languages, we add information on verbal or nominal affixation, which is discussed in the next section.

3. PRONOMINAL SYSTEMS. The pronominal paradigms (free and bound) of the East Papuan languages show a number of similarities to surrounding Oceanic languages. Some of these similarities are due to general typological tendencies, others may be due to diffusion. There are a number of typological features of pronominal systems that, according to Foley (I986) are typical of Papuan languages. These include: (a) stem alternations according to the person-number of core arguments (I28); (b) "restricted, abbreviated systems not commonly found elsewhere," for example, monofocal/polyfocal (67); (c) an unusual syncretism I.NON-SG $=2$. SG, found only in languages without an inclusive/exclusive distinction (72); and (d) different distinctions in pronominal systems in different parts of the grammar (67).

These features are not generally applicable to the East Papuan languages. The stemalternation feature indicated by Foley is found with some Yélî Dnye verbs, but is apparently absent in all the other Island Melanesian languages. The pronominal systems of the East Papuan languages are in general fairly full, with unique terms appearing for most person-number combinations and few syncretisms. Exceptional among the East Papuan languages is Yélî Dnye. Alone of all the Papuan languages, the postnuclear clitics of Yélî Dnye show the monofocal/polyfocal distinction found in some languages of highland PNG, and many Yélî Dnye prenuclear pronominal paradigms have a syncretism between 2 SG and IDU that might be related to the $2 . S G=I$.NON-SG syncretism noted by Foley. Cysouw (200I) shows that it is close to a linguistic universal for not-obviously-cognate pronominal markers to indicate different systems of distinctions. Of course, this is not to say that the actual distinctions made in the different pronominal systems are uninteresting; a language containing different pronominal systems offers much richer comparative potential than a language with a single system. The general conclusion is that the distinctive features of highland New Guinea Papuan languages are not distinctive of East Papuan languages. 
On the basis of geographic distribution, it might be expected that East Papuan languages are more heavily influenced by Austronesian languages than other Papuan languages, because East Papuan languages are surrounded by Austronesian languages, and generally do not form large contiguous zones. There is of course no reason to think that influence went only one way, and East Papuan languages are likely to have substrate and contact influence on Austronesian languages as well. Two common features of East Papuan languages that are shared by many Austronesian languages are the inclusive/exclusive distinction, and the existence of a dual

\section{TABLE 1. SYNTACTIC PATTERNS}

\begin{tabular}{|c|c|c|c|c|}
\hline LANGUAGE & $\begin{array}{l}\text { SENTENCE } \\
\text { CONSTITUTENTS }\end{array}$ & $\begin{array}{l}\text { PREPOSITION OR } \\
\text { POSTPOSITION }\end{array}$ & $\begin{array}{l}\text { POSSESSIVE } \\
\text { PHRASE }\end{array}$ & NOUN PHRASE \\
\hline \multicolumn{5}{|l|}{ NEW BRITAIN } \\
\hline Anêm & SVO Neg & $\operatorname{Pr}$ & $\mathrm{GN}_{(\mathrm{NG})}$ & NAD \\
\hline A ta : : & SVO Neg & $\mathrm{Pr}$ & $\mathrm{NG}::_{1}:$ & Art NAD \\
\hline Sulka & S Neg VO & $\operatorname{Pr}$ & $\mathrm{GN}_{(\mathrm{NG})}$ & Art NAD \\
\hline Koll: : : & S Neg VO viss & $\mathrm{Pr}$ & GN: & NAD : : \\
\hline Baining & Neg $S_{V O}(\mathrm{Vs})$ & Pr & GN & Art DNA \\
\hline Taulil. Butam & Neg SVO Ysis & Pr: : : : : : : : : : & GN: : : : & Ant DNA \\
\hline \multicolumn{5}{|c|}{$\begin{array}{l}\text { (Anêm and Ata: prefix or pro-clitic for subject, suffixing for object and possessor; Kol and } \\
\text { Sulka: prefixing for subject and possessor; Taulil and Baining not clear-only free pronouns? }\end{array}$} \\
\hline \multicolumn{5}{|l|}{ NEW IRELAND } \\
\hline Kuot & Neg VSO & $\mathrm{Pr}$ & NG & DNA \\
\hline
\end{tabular}

(subject and object are either prefix or suffix, depending on the verb)

BOUGAINVILLE

\begin{tabular}{|c|c|c|c|c|}
\hline Rotokas, Nasioi & SOV-neg & Po & $\mathrm{GN}$ & DNA \\
\hline Buin : : : : : : & SOV neg & Po & NG & DNA \\
\hline Motuna & SOV-neg & Po & $\mathrm{GN}_{(\mathrm{NG})}$ & Art DNA \\
\hline
\end{tabular}

(all of these basically suffixing; Motuna also has a possessive prefix)

SOLOMONS

\begin{tabular}{|c|c|c|c|c|}
\hline Bilua & S Neg VO & Po & GN & DAN \\
\hline Touo (Baniata) & SOV Neg & Po & GN & Art DAN \\
\hline Lavukaleve & SOV Neg & Po & GN & NAD Art \\
\hline Savosavo & SOV Neg. & Po & $G N$ & AnI NAD \\
\hline
\end{tabular}

(Bilua uses proclitics for subject and possessor; Touo has suffixing; Lavukaleve and Savosavo have both suffixing and prefixing, depending on the verb.)

ROSSEL ISLAND

$\begin{array}{lllll}\text { Yélî Dnye } & \text { SO Neg V } & \text { Po } & \text { GN } & \text { DNA }\end{array}$

SANTA CRUZ

Äŷiwo SV-neg $\mathrm{O}_{(\mathrm{vs})} \quad$ Pr $\quad$ NG $\quad$ NAD

(mainly suffixing for subject and possessor; $\ddot{A} \hat{y i w o ~ h a s ~ s u b j e c t ~ p r e f i x ~ f o r ~ i n t r a n s i t i v e ~ v e r b s) ~}$ 
number category. These two linguistic phenomena are important historically; if they can be shown to be innovations, they are potentially measures of the degree of Austronesian influence on Papuan languages or vice versa. On the other hand, if they can be shown to be archaic features, they then provide important information toward a typological profile of the original Papuan language or languages of the area.

Typologically, the classes of pronominal occurring in the East Papuan languages differ little from Austronesian languages. The most common types include invariant free pronouns, object/possessive affixes, and subject affixes.

3.1 INCLUSIVE/EXCLUSIVE DISTINCTIONS. An inclusive/exclusive distinction in the first person is common in Austronesian languages, and not generally typical of Papuan languages (Lynch I998: I00, I67). However, in the East Papuan languages, an inclusive/exclusive distinction is relatively common; in at least some cases, a diachronic path is detectable by which the language has innovated forms for this distinction using language-internal resources, such as a syncretism of 2PL and IDU inclusive (Lavukaleve, Bilua), or reanalysis of IDU as I PL inclusive (Motuna) (Ross 2000).

The inclusive/exclusive distinction is distributed in an orderly manner over most of Island Melanesia; it is found in the Papuan languages of New Ireland, West New Britain, North Bougainville, and the entire Solomons. It is lacking in East New Britain, some of South Bougainville, and in the Yélî Dnye language of Rossel Island. The Reefs-Santa Cruz languages form a special case, as they have a minimal-augmented system, a type of system that may be related historically to inclusive/exclusive systems, but that synchronically constitutes a separate type.

In some languages, inclusive/exclusive distinctions are found in a subset of the pronominal paradigms. For example, in Anêm, the inclusive/exclusive distinction is found in the possessive/object suffixes, but not in the subject prefixes (see table 2). In general typological terms, it is not unusual for two pronominal paradigms within a language to differ in the categories they express (Cysouw 200I). However, the inclusive/exclusive distinction is a feature of almost all Austronesian languages, but is rare in the Papuan languages of New Guinea (Lynch I998: IoO, I66). It is thus interesting to examine to what extent the inclusive/exclusive distinction can be shown to be an innovation in the East Papuan languages.

Ross (2000) shows that in Motuna the inclusive/exclusive distinction is an innovation from the ancestral South Bougainville language, with I PL exclusive coming from * IPL, and IPL inclusive coming from * IDU, while other dual terms were lost. Kol shares with Motuna the distinction of having an inclusive/exclusive distinction while lacking a dual; there is not enough evidence currently available from Kol to indicate whether lack of dual can be related to presence of the inclusive/exclusive distinction in this language, too.

In Lavukaleve, Bilua, and Ata, there are Ist person inclusive forms identical to 2nd person plural forms in certain pronominal systems. In each of these languages, this syncretism is not ubiquitous; in Ata it only occurs in a lexically determined subset of object/possessor suffixes, in Bilua it occurs in clitic pronouns, and in Lavukaleve it occurs only in pronominal prefixes. In none of these languages does it occur with free pronouns. 
Ata has three basic types of pronominal element: (I) free pronouns (one set) that distinguish inclusive and exclusive; (2) agent subject prefixes (two sets, marking aspect) with no inclusive/exclusive distinction; and (3) object/possessor suffixes (eleven sets, lexically determined) that do distinguish inclusive/exclusive. There is syncretism between IPL.INCL and 2PL in seven of the eleven sets. In Bilua and Lavukaleve, IPL.INCL $=2 \mathrm{PL}$ in all subject/object/possessor bound forms, but not in free pronouns. Note that the clitic pronoun forms in Bilua also have a syncretism between all first and second person dual forms. The forms are given in tables 3-5.

We hypothesize that the syncretism between Ist person inclusive and 2nd person plural is the result of an innovation, whereby the inclusive category has been created on the basis of the 2 nd plural.

3.2 MINIMAL-AUGMENTED SYSTEMS (SANTA CRUZ). The Santa Cruz languages (Northern Santa Cruz, Äŷiwo/Reefs, and Nanggu), which form a small genetic grouping, all use a minimal-augmented system for person-number reference. There is a certain amount of debate, not to be entered into here, about whether Santa Cruz languages are properly Papuan (itself a residual category), or whether they are deviant Austronesian. The traditional comparative method offers poor lexical evidence that the languages developed from Austronesian: lexical similarity counts are low with any other language, and there seems to be no evidence of regular sound changes that would link Proto-Santa Cruz to any other languages. Wurm has presented typological features to support the hypothesis that Santa Cruz languages are basically Papuan with significant admixture of Austronesian; Lincoln (I978) has argued the converse of this position, that Santa Cruz languages are Austronesian with high levels of Papuan influence.

With respect to the pronominal systems, the Santa Cruz languages are unique in the region. The dialects of Northern Santa Cruz distinguish singular from plural, and have a dual for the first person inclusive only; a better way of saying this would be to say there are four persons: I, I+2, 2, 3; and two categories analogous to number that can be called "minimal" and "augmented"- - the traditional number terms "singular" and "plural" not being properly applicable to such a system.

Additional support for this way of representing the pronouns comes from the neighboring Äŷiwo language. Äŷiwo makes another distinction: the "augmented" category is split by the addition of an affix -le deriving forms referring to "minimal number augmented by one" that can be called "unit-augmented." See table 6.5

Minimal-augmented pronoun systems do not occur in the Oceanic branch of Austronesian, but are common in the Philippines. They are quite rare worldwide. Apart from the minimal-augmented languages found in the Philippines, they are also found frequently in the non-Pama-Nyungan languages of northern Australia, as in the verb inflections of the Daly River languages and the independent pronouns of the Nyulnyulan languages (cf. Blake I988:7, I991:222). A minimal-augmented system is

5. Lincoln (I978:942) argues that the -le is a dual marker, possibly a reflex of POC *rua 'two'. Note also that the numeral 'two' in Äŷiwo is lilu, and in Santa Cruz is (a)li. However, an etymology for the unit-augmented affix based on a term for 'two' might be questioned, because the unit-augmented form of the $\mathrm{I}+2$ term actually refers to three individuals. 


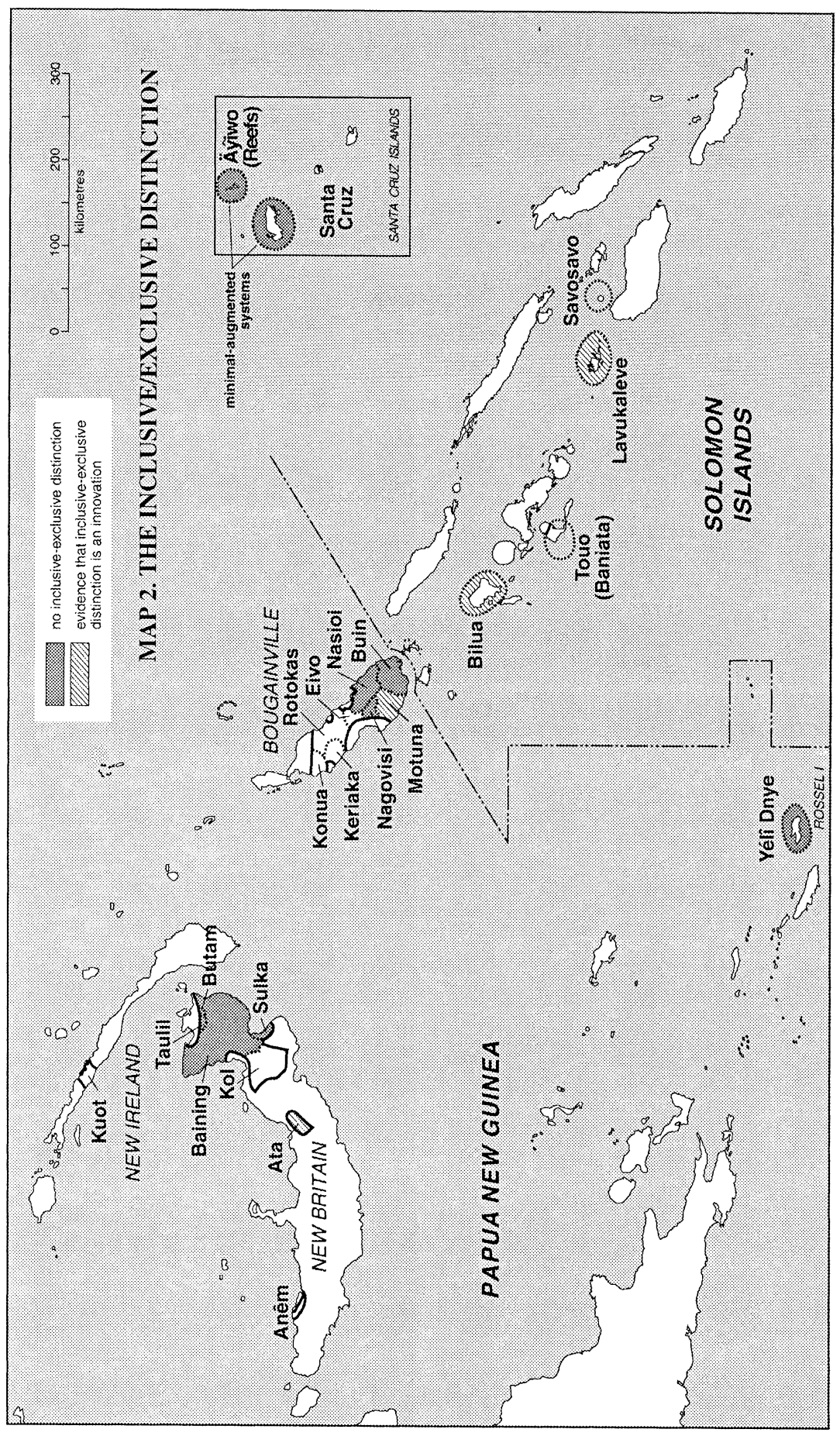


found in Tiwi, with an additional conflation of IPL and 2PL A minimal-augmented system is also found in the independent pronouns of Mountain Koiali (Papuan, southeastern PNG), but not in the other related Koiarian languages.

Cysouw (200I:2 IO) argues that minimal-augmented systems are most likely to develop from inclusive/exclusive systems, because minimal-augmented represents an incremental increase in the person number distinctions made by paradigms with inclusive/exclusive distinctions, which in turn are an incremental increase in the paradigms without inclusive/exclusive. Thus, the "first person plural" category in a language like English groups first person plus second person (me plus you), first person plus third

\section{TABLE 2. THE INCLUSIVE-EXCLUSIVE DISTINCTION IN ANÊM AFFIXES $\dagger$}

ANÊM SUBJECT PREFIXES

\begin{tabular}{|c|c|c|c|}
\hline I SG & a- & $\begin{array}{l}\text { IPLE.EXCl } \\
\text { I PI. INCL }\end{array}$ & $\mathrm{mi} / \mathrm{mi}$ \\
\hline $2 \mathrm{SG}$ & nî-/ni- & $2 \mathrm{PL}$ & $\eta \hat{\imath}-/ \eta \mathbf{i}-$ \\
\hline 3SG & u-/i- & 3PL & i- \\
\hline
\end{tabular}

ANÊM POSSESSIVE/OBJECT SUFFIXES

$\begin{array}{llll}\text { ISG } & \text {-i/-e/-at/-ai } & \text { I PL.EXCL } & \text {-în/-nit } \\ & & \text { I PL.INCL } & -i \mathrm{n} / \text {-nis } \\ \text { 2SG } & -\hat{i}(r) & \text { 2PL } & -\hat{i} y \\ \text { 3SG } & -\mathrm{u} /-\hat{i ̂ m} & \text { 3PL } & -\hat{i}\end{array}$

$\dagger \quad$ Source: Ross 2000. The Anêm free pronouns mark yet other categories; see 3.4.

TABLE 3. ATA PRONOMINAL ELEMENTS $\dagger$

FREE PRONOUNS

ISG eni IPL.EXCL nexi IPL.INCL nene

2SG nini 2PL yini 3SG.M anu 3PL ane'i 3SG.F ane

\section{AGENT SUBJECT PREFIXES}

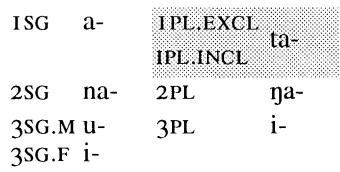

OBJECT/POSSESSOR SUFFIXES

ISG -lo IPL.EXCL - Xe IRL. INCL

$2 S$-ne 2 PI

3SG.M -u 3PL 3SG.F -e

$\dagger \quad$ Agent subject prefix examples are imperfective forms; there are also perfective. The object/possessor suffix forms are from class 4.5 (classes I, 4.3, 4.4, 4.5, 4.6, and 4.7 follow this pattern; classes $2,3,4 . \mathrm{I}, 4.2$, and 5 do not have the syncretism between IPL inclusive and 2PL). Source: Hashimoto n.d.:20, 23, 24.

\section{TABLE 4. BILUA PRONOMINAL ELEMENTS}

FREE PRONOUNS

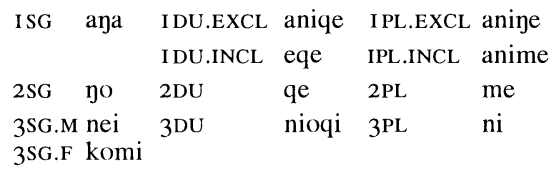

$+\quad$ Source: Obata 2000:52.

\begin{tabular}{|c|c|c|c|c|c|}
\hline \multicolumn{6}{|c|}{ SUBJECT/POSSESSIVE CLITIC FORMS $\dagger$} \\
\hline ISG & a & 1DU ExC1 & & I PL.EXCL & ne \\
\hline $2 \mathrm{SG}$ & no & 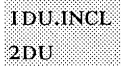 & ge & IPl. $\mathrm{INCl}$ & me \\
\hline 3SG. & & $3 \mathrm{DU}$ & qo & $3 P L$ & $\mathrm{ke}$ \\
\hline
\end{tabular}

\section{TABLE 5. LAVUKALEVE PRONOMINAL ELEMENTS}

FREE PRONOUNS

$\begin{array}{llllll}\text { ISG } & \text { ngai } & \text { IDU.EXCL } & \text { el } & \text { IPL.EXCL } \\ & & \text { IDU.INCL } & \text { mel } & \text { IPL.INCL } & \text { me } \\ \text { 2SG } & \text { inu } & \text { 2DU } & \text { imil } & \text { 2PL } & \text { imi }\end{array}$

(There are no third person free pronouns.)
SUBJECT/POSSESSOR PREFIX FORMS $†$

ISG a- IDU.EXCL le- IPL.EXCL eIDU.INCI Me- IPI.INCI

2SG yo- 2DU mele- 2PL

3SG o- 3DU lo- 3PL ma- 
person/s (me plus him/her/them), and first person plus second person plus third person/s (me plus you plus him/her/them). A language with inclusive/exclusive distinguishes "first person plural exclusive" (me plus him/her/them) from terms including second person (first plural inclusive, me plus you and possibly also him/her/them). Minimal-augmented systems make one further distinction that could be glossed 'first inclusive minimal' (me plus you) from first inclusive augmented (me plus you plus him/her/them). These systems are compared in table 7.

Whatever the ultimate conclusions about the origins of the Santa Cruz languages, the origin of the minimal-augmented system found therein is a mystery. If the origin of this system is local innovation (and it is hard to see where outside influence could have come from), then it is likely that a prior stage of the language had an inclusive/ exclusive distinction, but this itself could have been either inherited or diffused.

3.3. MONOFOCAL/POLYFOCAL PARADIGMS (YÉLÎI DNYE). The Yélî Dnye language shows traces of a monofocal/polyfocal system. This is a system in which there is an opposition between first person and singular forms versus nonfirst person, nonsingular terms. In Yélî Dnye, this distinction is found in the postnuclear pronominal paradigm. The fact that the same distinctions are found in the New Guinea highlands suggests the possibility of ancient links. The monofocal/polyfocal opposition is illustrated with the verb $m a$ 'eat' in table 8, where the forms for ' $\mathrm{X}$ ate them' are given. The pre- and postnuclear elements are complex portmanteau clitics, indicating tense/aspect/mood and person/number of both subject and object. The postnuclear clitics té and $t: 0 o$ follow a monofocal/polyfocal pattern.

The Yélî Dnye prenuclear clitics do not show any obvious trace of a monofo$\mathrm{cal} /$ polyfocal system. However, for many of them, the $2 \mathrm{SG}$ term is identical to IDU, which, as mentioned earlier, may be related to the common syncretism of $2 \mathrm{SG}=$ I PL-NONSG. This syncretism is typologically unusual, but is common in New Guinea, and so is likewise suggestive of linguistic relationships to New Guinea Papuan languages.

\section{TABLE 6. SANTA CRUZ AND ÄŶIWO FREE PRONOUNS}

\begin{tabular}{|c|c|c|c|c|c|}
\hline \multicolumn{3}{|c|}{ SANTA CRUZ } & \multicolumn{3}{|l|}{ ÄŶIWO } \\
\hline MINIMAL & AUGMENTED & & MINIMAL & UNIT AUGMENTED & AUGMENTED \\
\hline ninä & nigö & I & in & injugo-le & injo \\
\hline nigi & nigu & $I+2$ & inudyi & inude-le & inde \\
\hline nim & nimu & 2 & inumu & inumi-le & jumi \\
\hline nide & nidõ & 3 & iuna & iudyi-le & iudyi \\
\hline
\end{tabular}

TABLE 7. COMPARISON OF PLURAL SYSTEMS
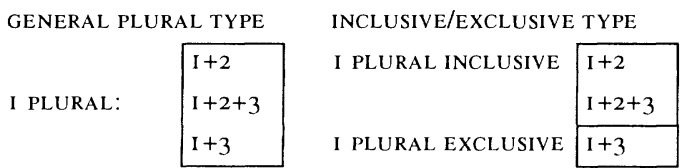

MINIMAL-AUGMENTED TYPE

\begin{tabular}{l|l|} 
I INCL MINIMAL & I +2 \\
\hline I INCL AUGMENTED & I $+2+3$ \\
\hline I EXCL & I +3 \\
\hline
\end{tabular}


3.4 DUAL AND TRIAL NUMBER CATEGORIES. The East Papuan languages typically mark the number categories singular and plural with some or all of their pronominal forms. Most East Papuan languages also have a dual; of the languages with a singular and plural, the only languages without a dual are Kol (New Britain) and Motuna (Bougainville). (Santa Cruz languages do not distinguish singular and plural, and should be considered separately.) Anêm (New Britain) and Touo (Baniata) (Solomon Islands) are unusual in having four number values.

Anêm has partial paradigms of dual and trial (see table 9). These occur in free pronouns only. In first person exclusive, second person, and third person, the Anêm dual and trial pronouns are formed by means of a separable morpheme added to the plural form. According to Johnston (1980:54), niak means 'two' and bik means 'three'. Only in the first person inclusive forms does it look like this morpheme has fused into a single grammatical form. This makes both dual and trial look like recent innovations in the language.

Touo marks four number categories; singular, dual, known-quantity plural, and unknown-quantity plural, as shown in the free pronouns given in table Io. These four categories are also marked on prenominal particles and number suffixes of nouns (the forms are mostly the same as the third person personal pronouns). The indefinite article and the demonstratives mark singular and plural only. The object suffixes show massive syncretism; see table II. The similarities between the free pronouns and the object suffixes are marginal, and are probably not significant, considering that such a rich system is compared to such a poor one. Thus, we would not want to argue that the Touo object suffixes provide evidence that dual and/or known plural are innovations attributable to diffusion.

As discussed in 3.2, the Santa Cruz languages have a person-number system for which the number categories singular/dual/plural are not the organizing categories. Santa Cruz proper has two numbers (or "number-like categories"), minimal and augmented, whereas neighboring Äŷiwo has three: minimal, unit-augmented, and augmented. These systems are analogous to singular/plural and singular/dual/plural respectively. The unitaugmented category in Äyiwo is a clear innovation, as all forms are based on the corresponding augmented category with the addition of a suffix - $l e$ ( $\left(\operatorname{see}_{3} 3.2\right)$.

\section{TABLE 8. "X ATE THEM” IN YÉLî DNYE†}

$$
\begin{aligned}
& \text { ISG nîma té } \\
& \text { 2SG nyi ma té } \\
& \text { 3SG ma té }
\end{aligned}
$$

\begin{tabular}{|c|c|}
\hline I DU & nyi ma té \\
\hline 210u & dpi na t.o \\
\hline & ma t:o \\
\hline
\end{tabular}

IPL nmî ma té

2PI nmyi ma t.00

3Pl: na $1: 00$

Source: Henderson 1995:39

\section{TABLE 9. ANÊM FREE PRONOUNS †}

$\begin{array}{llllllll}\text { ISG } & \text { ue } & \text { IDU.EXCL } & \text { mûn niak } & \text { ITR.EXCL } & \text { mûn bik } & \text { IPL.EXCL } & \text { mûn } \\ & & \text { IDU.INCL } & \text { miak } & \text { ITR.INCL } & \text { mibik } & \text { IPL.INCL } & \text { min } \\ \text { 2SG } & \text { nin } & \text { 2DU } & \text { niak } & \text { 2TR } & \text { bik } & \text { 2PL } & \emptyset \\ \text { 3SG } & \text { (D) } & \text { 3DU } & \text { (D) niak } & \text { 3TR } & \text { (D) bik } & \text { 3PL } & \text { (D) }\end{array}$

$\dagger \quad$ Source: Ross 2000. Demonstratives are used in place of third person pronouns. 
The dual category is also nearly ubiquitous in Island Melanesia among both East Papuan and Oceanic languages. In the East Papuan languages, it is lacking in only two of the languages with a singular-plural distinction. In Southern Bougainville, Motuna lacks a dual. However, based on comparison of the pronoun forms, Ross hypothesizes a dual for the ancestor language. Evidence for this is the Motuna Ist person plural inclusive pronoun, which he suggests is cognate to ist person dual pronouns in Nasioi, Nagovisi, and Buin (Ross 2000).

There is no evidence that there was ever a dual in the New Britain language Kol.

To the west of Kol, separated by Austronesian languages, the only Papuan languages are Ata and Anêm. Anêm has a dual that seems to be a recent formation on the basis of the numeral 'two'. Ata shows many similarities to Anêm, and it is located between $\mathrm{Kol}$ and Anêm. If there were evidence that the Ata dual was an innovation, it would unite the three languages typologically and geographically. This, however, does not prove to be true. The Ata dual, like Anêm, occurs in free pronouns only. See table 12.

According to Yanagida (pers. comm.), the dual forms are a kind of compound; the first element (identical to the plural pronouns) can be omitted under certain

TABLE 10. TOUO FREE PRONOUNS $\dagger$

\begin{tabular}{|c|c|c|c|c|}
\hline \multirow{3}{*}{$\begin{array}{l}\text { IEXCL.M } \\
\text { IEXCL.F }\end{array}$} & SINGULAR & DUAL & KNOWN PLURAL & UNKNOWN PLURAL \\
\hline & \multirow{4}{*}{ yei } & \multirow{7}{*}{$\begin{array}{l}\text { yere } \\
\text { yerebe } \\
\text { be } \\
\text { bebe } \\
\text { bere } \\
\text { berebe } \\
\text { zere } \\
\text { robe }\end{array}$} & \multirow{6}{*}{$\begin{array}{l}\text { yebenw } \\
\text { yebenu } \\
\text { menw } \\
\text { menu } \\
\text { mebenw } \\
\text { mebenu } \\
\text { nwmw }\end{array}$} & yebw \\
\hline & & & & \\
\hline I INCL.M & & & & memw \\
\hline I INCL.F & & & & \\
\hline $\begin{array}{l}2 \mathrm{M} \\
2 \mathrm{~F}\end{array}$ & noe & & & mebw \\
\hline $3 \mathrm{M}$ & zo & & & mw \\
\hline $3 \mathrm{~F}$ & vo & & numw & 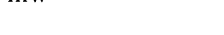 \\
\hline $\begin{array}{l}3 \mathrm{~N}-\mathrm{I} \\
3 \mathrm{~N}-2\end{array}$ & $\begin{array}{l}\text { na } \\
\text { ngw }\end{array}$ & rede & nafi & nw \\
\hline
\end{tabular}

$\dagger \quad$ Orthographic $w$ indicates $/ \% /, n g$ indicates $/ \mathrm{g} /, r$ indicates the lateral flap $/ 1 /$, and $y$ indicates breathy voice quality on the following vowel (see Terrill and Dunn forthcoming); source: Terrill and Dunn fieldnotes.

TABLE 11. TOUO OBJECT SUFFIXES $\dagger$

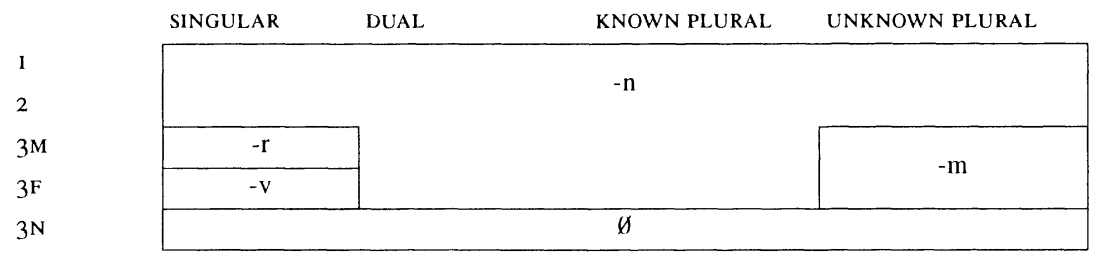

$\uparrow \quad$ Source: Terrill and Dunn 200 I fieldnotes 
discourse conditions. While this makes the Ata dual look somewhat synthetic, the second element of the compound has a variety of forms, and there is no analyzable common element indicating 'dual' ${ }^{6}$ Thus, there is nothing to suggest that the Ata dual is not archaic.

All other East Papuan languages have a well-established dual, and in most cases there is no evidence that the dual category is recently derived from the numeral 'two'. In the New Britain/New Ireland languages, the numeral stems for 'two' show no similarity to dual affixes. In Butam, the numeral 'two' includes what is apparently the dual suffix (mukumip, mugumip 'two', -ip dual suffix [Laufer 1959:209]), but this does not suggest that the morphemes have a common origin (compare Taulil mukom 'two', -ip dual masculine suffix [Laufer I950:638]). In the Bougainville languages with a dual category (i.e., all except Nasioi and Motuna), each language has several different dual forms. There is no pattern suggesting any language-internal reconstruction of a single morpheme, and there are few forms showing even distant similarity to the numeral 'two'. In the Papuan languages of the Solomon Islands, Bilua, Touo, and Savosavo show no similarities between dual and 'two'. In Lavukaleve, the numerals for 'two' look like they are diachronically segmentable into a stem and a dual gender suffix: lelemal (MASC), le'laol (FEM), lelagel (NEUT), lemal (counting form). The dual adj/verb agreement suffixes are: -mal (MASC), -aol (FEM), -gel (NEUT) (Terrill I999:50, 223).

It is conceivable that both the stems for 'two' and the dual suffixes are derived from a common source. Many other dual affixes in the language include the segment $l$. It is possible that the ubiquity of $l$ in dual and 'two' forms indicates that the dual category is a relatively recent innovation in Lavukaleve.

In general, the possibility cannot be precluded that the existence of the dual in Papuan predates Austronesian influence. Oceanic Austronesian languages typically have singular/dual/plural, although there are a few with singular/plural only. According to Ross (1988: 97-98, IOO-IOI), dual in Oceanic is either an innovation of Oceanic as a whole, or of a number of Oceanic subgroups. Dual is reconstructed for Proto-Oceanic as formed by grammaticalization of the numeral *rua 'two' as a suffix (trials and perhaps paucals are also reconstructed on the basis of *tolu 'three' and *pat 'four', respectively). If the Austronesian languages arrived

TABLE 12. ATA DUAL AND PLURAL FREE PRONOUNS $\dagger$

\begin{tabular}{|c|c|c|}
\hline $\begin{array}{l}\text { I DU.EXCL.M } \\
\text { I DU.EXCL.F }\end{array}$ & $\begin{array}{l}\text { nexi-noxou } \\
\text { nexi-noxie }\end{array}$ & I PL.EXCL \\
\hline IDU.INCL & neye-nenei & IPL.INCL \\
\hline $\begin{array}{l}\text { 2DU.M } \\
\text { 2DU.F }\end{array}$ & $\begin{array}{l}\text { yini-noyou } \\
\text { nipi-noyie }\end{array}$ & $2 \mathrm{PL}$ \\
\hline $\begin{array}{l}\text { 3DU.M } \\
\text { 3DU.F }\end{array}$ & $\begin{array}{l}\text { ane'i-ilou } \\
\text { ane'i-ilee }\end{array}$ & $3 \mathrm{PL}$ \\
\hline
\end{tabular}

6. The numeral 'two' in Ata is taamei (Yanagida, pers. comm.). 
in Island Melanesia without the duals already in place, it would be possible that the innovation of dual in Proto-Oceanic is a result of diffusion or substrate influence from East Papuan.

3.5 SUMMARY. The typological comparison of pronominal systems suggests a number of clusters. Yélî Dnye at one end of the region and Äŷiwo/Santa Cruz at the other are outliers typologically as well as geographically. Yélî Dnye is the only language with evidence of a monofocal/polyfocal system, and Äŷiwo and Santa Cruz are the only languages with minimal-augmented structures.

Dual is ubiquitous in the East Papuan languages. Only Kol has no evidence of ever having a dual, and Motuna is the only other language lacking a dual synchronically. The Oceanic branch of Austronesian has a dual that cannot be reconstructed to pre-Oceanic, and it is thus possible that it is a result of Papuan influence.

The inclusive/exclusive distinction is distributed in geographic clusters (see figure I and table I3); absence of the inclusive/exclusive distinction seems to be an archaic feature of East Papuan languages, and presence of the inclusive/exclusive distinction is in at least some cases an innovation that could be the result of Austronesian influence.

4. VERBAL MORPHOLOGY. Most East Papuan languages have rather complex verbal morphology, with many types of category marked on the verb. This section begins by discussing the general structure of verbs in East Papuan languages, and the structural properties of verbal affixes and the types of categories marked. The aim is to find to what extent generalizations can be made about features of morphology associated with verbs in East Papuan languages. The main focus of this section is an examination of pronominal affixes on verbs, looking at principles determining in what position (pre- or postverbal, or a combination of both) the syntactic arguments of verbs are marked. In this section, we confine ourselves to verbal affixes, and do not discuss clitics.

\section{TABLE 13. SUMMARY OF PRONOMINAL FEATURES}

$\begin{array}{llllll} & \text { INCL/EXCL } & \text { DUAL } & & \text { INCL/EXCL } & \text { DUAL } \\ \text { New Britain: Anêm } & \text { yes } & \text { yes } \dagger & \text { Bougainville: Konua } & \text { no } & \text { yes } \\ \text { New Britain: Ata } & \text { yes† } & \text { yes } & \text { Bougainville: Nagovisi } & \text { no? } & \text { yes } \\ \text { New Britain: Kol } & \text { yes } & \text { no } & \text { Bougainville: Motuna } & \text { yes } \dagger & \text { noł } \\ \text { New Britain: Sulka } & \text { no } & \text { yes } & \text { Bougainville: Buin } & \text { no } & \text { yes } \\ \text { New Britain: Taulil } & \text { no } & \text { yes } & \text { Bougainville: Koromira } & \text { no } & \text { yes } \\ \text { New Britain: Baining } & \text { no } & \text { yes } & \text { Solomons: Bilua } & \text { yes } \dagger & \text { yes } \\ \text { New Britain: Butam } & \text { no } & \text { yes } & \text { Solomons: Touo (Baniata) yes } & \text { yes } \\ \text { New Ireland: Kuot } & \text { yes } & \text { yes } & \text { Solomons: Lavukaleve } & \text { yes } \dagger & \text { yes } \dagger \\ \text { Bougainville: Nasioi } & \text { no } & \text { yes } & \text { Solomons: Savosavo } & \text { yes } & \text { yes } \\ \text { Bougainville: Rotokas } & \text { yes } & \text { yes } & & & \end{array}$


Generalizations can for the most part be made most usefully about each major area within the East Papuan group (Bismarcks, Bougainville, Central Solomon Islands, Rossel, and Santa Cruz). Accordingly, most topics will be discussed with respect to each of these geographical groupings.

\subsection{GENERAL OUTLINE OF VERB STRUCTURE}

4.1.1 Segmentability of morphemes. Verbal morphology is generally reasonably segmentable in the East Papuan languages. In Anêm there is widespread verb stem suppletion, and in the Bismarcks and Bougainville generally there is a large degree of morphological alternation in affix forms, creating large numbers of paradigms for certain categories. In the Central Solomon Islands, morphemes are more transparent, being largely segmentable, apart from a few exceptions in each of the languages. In Yélî Dnye, however, verbal morphology is typically expressed by portmanteau morphemes, with a high degree of unpredictable variation in different categories.

\subsubsection{General structure of verbal morphology and types of categories marked.} Anêm has prefixes marking subject/mood, and suffixes marking verb class and object (Thurston 1982). Ata has prefixes marking subject/aspect, and suffixes marking verb class/object (Hashimoto n.d.). Both Anêm and Ata make a primary distinction in their verb morphology between a small number of verb classes. Apart from subject/mood or subject /aspect prefixes and class/object suffixes, neither language makes further distinctions in its verbal morphology.

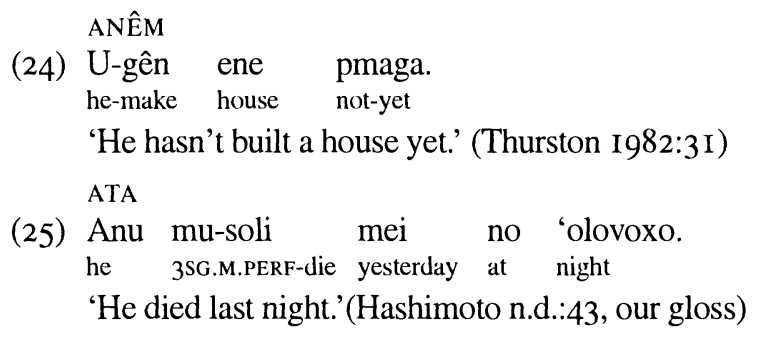

Sulka has mostly prefixes, with a few suffixes. The prefixes mark subject/tense and negation, and other aspects or moods, and there are some transitivising suffixes (Tharp 1996). Objects are marked by free forms, not by affixes. For example:

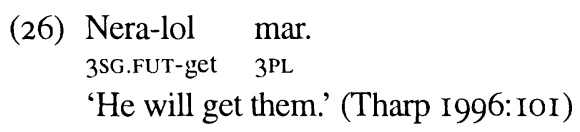

Baining has only tense prefixes (Parker and Parker 1977). Other categories are marked by separate particles. See example (27).

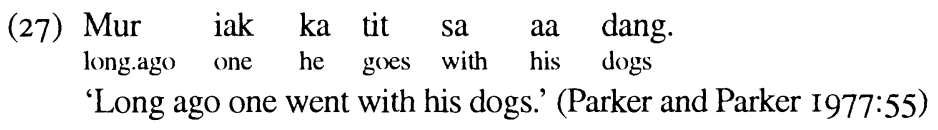

Taulil appears to have no verb affixes. Core arguments are expressed as free pronouns, and tense/aspect/mood is expressed through particles, as in (28). 
(28) Ga kia matma.

Isg earlier work

'I worked earlier.' (Laufer I950:637, our gloss and translation)

Kuot has prefixes and suffixes for subject and object marking; tense is expressed within certain subject and object markers, and there are also prefixes for reflexive, reciprocal, "pluractional," and "dummy objects" (Eva Lindström, pers. comm.) For example:

$\begin{array}{lll}\text { (29) U-la } & \text { a-ko-on } & \text { ubianəma. } \\ \text { 3M.S-go } & \text { 3m.O-throw-3m.S } & \text { fishnet(m) }\end{array}$

'He went (and) threw the fishnet.' (Lindström, pers. comm.)

All verbal morphology of the Bougainville languages Motuna, Nasioi, Buin, and Koromira is expressed as suffixes. Rotokas is likewise predominantly suffixing, its only prefix being a reciprocal marker.

Motuna makes a primary distinction between active and middle verbs, the choice determining much of the other morphology on the verb (Onishi I994). Besides marking subject and object, verbs also mark negation, gender, switch reference, and TAM (including I4 separate categories for nonmedial verbs, or 5 for medial verbs). For example:

(30) Taapu-r-opi-ti-hee. help-2O-I S-DU-DEF.FUT

'We two will definitely help you (SG)' or 'I will definitely help you two.' (Onishi 1994:256)

Buin, like Motuna, distinguishes stative and dynamic verb forms (Laycock and Onishi n.d.). Subject forms vary according to tense/aspect and other factors. There are four tense/aspects, with further forms distinguishing benefactive, causative, reciprocal, reflexive, impersonal, and multiple object.

Nasioi has four classes of verb stem distinguishing transitivity types; each verb class has its own slightly different variant of person and number markers. Some classes have both bound and free variants of verbs. In some classes these are the same form; in others they are different forms. Number is marked, in a rather complex way, and there are nine tense/aspect combinations. For future and present categories, there are positive and negative forms. There are also suffixes for volitional, avolitional, subjunctive, traditional, durational, and neutral. Relational markers are used on dependent verbs. They mark same or different subject, and whether the action changes presently or immediately, or whether it continues at length or briefly, or whether it coordinates (Hurd and Hurd 1970). An example of some of this morphology is given in (3I).

(3I) Paku-m-e-de-ain. help-me-you-DU-will

'You two [will] help me.'(Hurd and Hurd 1970:4I)

Koromira verbs inflect for first and second person, and for perfect, present, future positive, and future negative (Rausch I9I2:969ff). Verbs also include number (of subject) (SG, DU, PL), and object and indirect-object marking, all of which 
is done by suffixes. There are reflexive forms, too, and there are irregular verbs as well: go, come, be/stay. Rausch also mentions passives, relative and adverbial clauses, infinitives, and so on.

In Rotokas there are two stem types. The stem class of verb determines the type of person-number and nonfuture tense markers (Firchow 1987:23): the classes correspond largely, though not entirely, to transitivity (22-32). There are two future tense categories, near future and distant future. There is also present tense and four past tenses: immediate past, near past, distant past, and remote past. (20-2I). Firchow notes that verbs have far more complex morphophonemics than other word classes (I987: I5). An example of one of these tenses is given in (32).

(32) Aio-ri-verea.

eat-you-DIST.FuT

'You will eat it years from now.' (Firchow 1987:20)

In the Central Solomon Islands, Touo (Baniata) expresses only object and mood with verbal suffixes, other verbal categories being expressed by clitics (Terrill and Dunn I 995 fieldnotes). Touo verbs make a basic modal distinction between realis or irrealis mood. Tense is just future/nonfuture. Aspect is progressive/nonprogressive, with possibly a perfective particle, and perhaps a continuous particle. Other aspectual information is expressed phrasally with serial verb constructions. Subjects are not marked on the verb, but rather in free pronouns or proclitics, and objects are marked by verbal suffixes. For example:

(33) Vo yuse ia bae-v-a.

3SG.F bottle already break-3SG.F-REAL

'(Someone) broke the bottle.'(Terrill and Dunn I995 fieldnotes)

Bilua (Obata 2000) expresses all verbal categories with clitics rather than affixes. There are six tenses and one mood, the imperative, the markers of which agree with the addressee in number. There are four aspectual/modal markers. If tense is marked, aspect/mood must also be marked. Otherwise, aspect/mood is optional. There are also possessor-raising and valency-increasing clitics.

In Lavukaleve, there are prefixes and suffixes for subject and object. Other verbal categories are all expressed by suffixes, and include two marked tenses: future and present; two aspects: imperfective and durative; and five moods: admonitive, punctual imperative, durative imperative, hortative, and abilitative. The imperatives are further marked for number (SG, DU, PL) of the subject. There are also further suffixes including negation and extension. There is a causative suffix and a rather unproductive intransitivizer, and several other minor suffixes as well (Terrill I999).

Savosavo verbs can take object prefixes or suffixes, and the position of other verbal morphology is unknown (Todd 1975, Terrill and Dunn I995 fieldnotes). This is exemplified in (47-5I) on 55.

On Rossel, Yélî Dnye has what Henderson (I995) calls a verbal prenucleus, containing TAM and person/number of subject, and a postnucleus containing TAM and object person/number. There are no verbal affixes. 
(34) Kaawa ngê dê

Kaawa SG.ERG PUNCT.INDIC.IMMEDIATE PAST.3.S

m:uu té.

See TRANS.PUNCT.INDIC.PROX.3PL.O.MONOFOCAL

'Kaawa saw them.' (Henderson I995:I5)

(35)
Saw nt:u ngmê-nî
nuwo.
saw body INDEF-PUNCT.INDIC.REMOTE PAST.ISG.S
take.REMOTE PAST

'I took a (circular) saw blade.' (Henderson I995: I5)

In Santa Cruz, both Äŷiwo and Northern Santa Cruz are mostly suffixing, with only limited categories expressed by prefixes. Äŷiwo has aspect/intransitive subject prefixes and transitive subject and object suffixes; it also has instrumental verb prefixes (e.g., by hand, with a tool), and other affixes are unknown (data from Wurm 1992a). Northern Santa Cruz has seven prefix slots (for location, negation, subject, aspect, indefinite object, and causative); and 23 suffix slots, expressing meanings including change of state, accompaniment, object focus, reflexive, directionals, aspectuals, adverbials, instrumental, benefactive, negation, subject, and 3PL object). There are subject and object suffixes, and 3PL subject has a prefix as well (all data from Wurm I992a).

4.2 PERSON MARKING ON VERBS. All the East Papuan languages considered have nominative/accusative systems in their verbal morphology, under which subjects (transitive or intransitive) are morphosyntactically distinct from objects, although in certain types of subordinate clauses Lavukaleve has an ergative/absolutive marking system (but see our comment in 2.I with respect to "experiential verbs").

Most East Papuan languages do mark their basic arguments by affixation to the verb. Only Yélî Dnye (Rossel), Baining, Taulil, Bilua, Touo (Baniata), and Savosavo do not mark subjects by affix, but rather by proclitics in the case of Yélî Dnye, Bilua, and Touo, and by free pronouns in the case of Baining and Savosavo. Baining, Taulil, Sulka, Bilua, and Yélî Dnye are the only languages that do not mark their objects by affix. Bilua instead uses enclitics, Baining uses free pronouns, and Yélî Dnye uses enclitics.

Some of the East Papuan languages have a variety of positions available for subject and/or object marking. The position depends on factors like TAM categories also marked on the verb and predicate type or verb class. These will be discussed more fully in the next sections. The rest of the discussion concerns only those languages that do have subject and/or object affixation.

4.2.1 Subject affixation. The suffix position is by far the most common option for the subject marking affix in East Papuan languages. In fact, of all the East Papuan languages considered, only Anêm and Sulka do not have, at least as an option, a subject suffix rather than a prefix.

For all the languages of Bougainville considered (Rotokas, Koromira, Motuna, Nasioi, Buin), and for Northern Santa Cruz, a suffix is the only possibility for subject marking (although Northern Santa Cruz has an optional part of a 3PL subject 
prefix). For Kuot, Lavukaleve, and Ä̂̂iwo, subjects can be marked by prefix or by suffix; the conditions vary with each language.

In Kuot, there are four verb classes that differ, among other things, in the position in which they mark their core participants. The possibilities are given in table I4 (all data from Eva Lindström, pers. comm.). Of these, only Class I is productive and, interestingly, seems to be an innovative structure. The others are all small classes with few members and are apparently archaic. Some examples are given in (36-40).

(36) a-pasei-on

3MO-talk-3mS

'he talks of him' or 'he tells him'

(37) u-alibə-o

3MS-cry.for-3FO

'he cries for her'

(39) a-u-lo

3MO-3mS-tell

'he tells him'

(38) to-u-alibə

IsO-3mS-cry.for

'he cries for me'

(40) a-uan-u-lə

3MO-wait-3MS- $\mathrm{STM}_{2}$

'he waits for him'

In Lavukaleve, the choice between prefix or suffix for subjects is complex. There are two prefix positions, one for person/number of subject and one for person/number/gender of object, and there is a suffix position for number/gender as well as one for tense/aspect/mood/negative markers. Subject and object can be cross-referenced only once per predicate, either by a prefix or by the suffix. The choice between prefix or suffix is determined by various interconnected factors, including predicate type and focus construction type. The possible structures of simple predicates in main clauses are given in table $\mathrm{I} 5$.

Complex predicate types and predicates in nonmain clauses each have different participant marking structures again, but for every predicate in the language, the basic principle is that each argument, subject or object, can be marked only once per predicate. Object marking is always obligatory, but subject marking is in most circumstances not, and is in some circumstances not allowed (Terrill I999).

\section{TABLE 14. KUOT VERB CLASSES}

\begin{tabular}{|c|c|c|c|}
\hline VERB CLASS & SUBJECT & OBJECT & STRUCTURE \\
\hline 1 & enclitic & prefix & $0-V_{-S}$ \\
\hline IIa & prefix & $\begin{array}{l}\text { suffix for } 3 \text { rd person } \\
\text { prefix for I st } / 2 \text { nd person }\end{array}$ & $\begin{array}{l}\mathrm{s}-\mathrm{V}-\mathrm{o} \\
\mathrm{o}-\mathrm{s}-\mathrm{V}\end{array}$ \\
\hline IIb & prefix & prefix & $0-5-V$ \\
\hline III & infix & prefix & $\mathrm{o}-\mathrm{V}-\mathrm{s}-\mathrm{V}$ \\
\hline
\end{tabular}

TABLE 15. POSSIBLE STRUCTURES OF PREDICATES IN LAVUKALEVE

\begin{tabular}{|c|c|c|c|}
\hline s- & V & $-\mathrm{TAM} / \mathrm{NEG}$ & \\
\hline o- & $\mathrm{V}$ & $-\mathrm{TAM} / \mathrm{NEG}$ & -gender/number of S \\
\hline s- & $\mathrm{V}$ & $-\mathrm{TAM} / \mathrm{NEG}$ & -gender/number of $\mathrm{O}$ \\
\hline
\end{tabular}


Some examples of some possible participant-marking strategies are given in (4I-43).

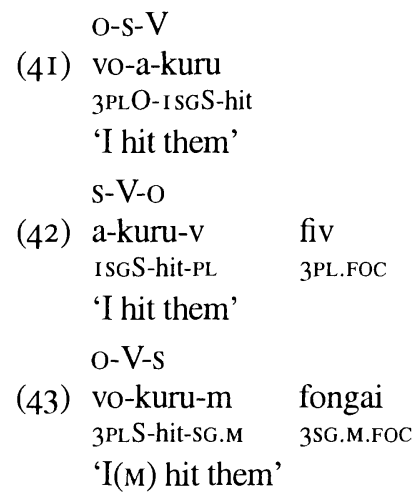

Note that focus is implicated in the latter two examples; the last example in particular is strongly marked in terms of information structure.

In $\ddot{A} \hat{i}$ iwo, marking subjects with a prefix versus a suffix depends solely on transitivity: intransitive subjects are marked with prefixes, and transitive subjects are marked with suffixes. For example:

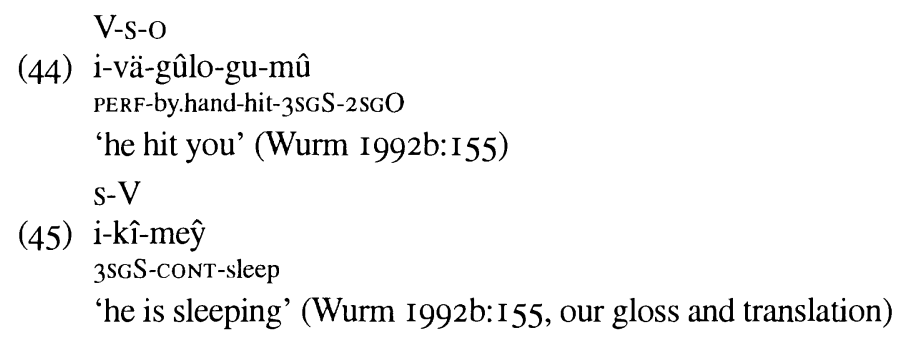

In Northern Santa Cruz, subjects are marked by suffixes, except for the 3PL affix, which is a discontinuous morpheme, the first part of which can precede the verb stem (Wurm I992a:529). An example of this morpheme:

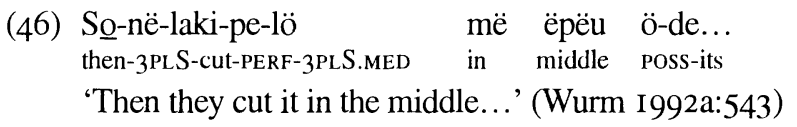

4.2.2 Object affixation. Object affixation is more widespread than subject affixation in the East Papuan languages. Every one of the languages that mark objects by affixation can mark their object with a suffix: for most languages, this is the only choice. Thus, Anêm and Ata in New Britain, Rotokas, Nasioi, Buin, and Motuna in Bougainville, Touo (Baniata) in the Central Solomon Islands, and seemingly Äŷiwo in Santa Cruz have objects marked always by suffix.

Kuot, Lavukaleve, and Savosavo have the choice of marking object by prefix or by suffix. The choice in Kuot is determined by verb class, as described above. For Lavukaleve, the choice is determined by predicate type, TAM, and focus marking, among other things, as was also described above. For Savosavo, most verbs take an object suffix, but some take an object prefix instead (Todd I975:8 I 5). For example: 
(47) Misu-na lo polo l-oi. dog-S 3SG.M pig 3SG.M.O-bite

'The dog bit the pig.' (Terrill and Dunn 1995 fieldnotes)

(48) Anyi so mata-li.

ISG banana( $M$ ) want-3SG.MO

'I want a banana.' (Terrill and Dunn 1995 fieldnotes)

Sometimes a suffix can mark subject or object.

(49) Anyi no sondo-anyi.

ISG 2SG see-ISG

'I saw you.' (Terrill and Dunn 1995 fieldnotes)

(50) No-na anyi sondo-anyi.

2SG-S ISG see-ISG

'You saw me.' (Terrill and Dunn I995 fieldnotes)

Compare this ISG suffix with the ISG prefix in (5I).

(5I) Misu-na ny-o-i.

dog-S ISGO-bite-?

'Dog bites me.'(Terrill and Dunn 1995 fieldnotes)

The participant marking in Savosavo is little understood; far more data are needed in order to be able to understand the decisive factors. However, we can at least say that there is variability in Savosavo between cross-referencing subjects and objects on verbs, and using prefixes and suffixes to mark these categories.

The Santa Cruz languages are a little complicated. In Äŷiwo, person and number of the object are often indicated by a suffix added after the subject suffix (Wurm 1969:85, 87) as in (52).

(52) La-ba-i-ämoli-wa-ne-mi-le-gu-naa.

PROG-NEG-PERF-See.NONI-BEN2-ISGS-2O-DU-NEG-PROG 7

'I did not see you two.' (Wurm I969:79)

In Northern Santa Cruz, object suffixes are optional and limited to the 3rd person only, often giving a partitive meaning (Wurm I992a:529). An example is (53).

(53) Në-tapu-pä-lö-kongü nëlu.

3PLS-split-outwards-3PLS.MED-3PLO coconut

'They split some coconuts.' (Wurm I992a:550)

4.3 GENERAL COMMENTS ON VERB STRUCTURE. Table I 6 summarizes the positions of verb affixes marking major participants found in East Papuan languages. The pattern for participant marking in Oceanic languages is $\mathrm{S} \mathrm{V}$-o, where $\mathrm{S}$ is typically a proclitic or free pronoun appearing before the verb, and $\mathrm{O}$ is a verbal suffix. This pattern is evidenced in Touo (Baniata) and in one marking pattern in Savosavo, both in the Central Solomon Islands group. Casting the net slightly wider, languages that evidence an $\mathrm{s}-\mathrm{V}-\mathrm{o}$ marking pattern are reasonably

7. non $\mathrm{I}=$ nonfirst person; ben $2=$ benefactive second person 
common among the East Papuan group. These languages include Anêm, Ata, one marking pattern in Kuot, a marking pattern in Lavukaleve, a marking pattern in Savosavo, and a marking pattern in Reefs.

On the other hand, there are a number of languages that have the most common mainland Papuan patterns: marking their subjects after the verb, and their objects before the verb (Foley 1986: I38). These patterns are not typical of Oceanic languages. Languages that mark their subjects after the verb include the languages of Bougainville, a marking pattern in Kuot, a marking pattern in Lavukaleve, and a marking pattern in Reefs. Languages that mark their objects before the verb include one marking pattern in Kuot, a marking pattern in Lavukaleve, and a marking pattern in Savosavo.

Kuot, Lavukaleve, and Savosavo are also interesting in that they all have a number of possible positions for marking their core participants, depending on various factors. In Kuot the relevant factors are verb class, in Lavukaleve it is predicate type, focus type, and TAM, and in Savosavo the factors are unknown. This should be a fruitful area for future research.

\section{TABLE 16. POSITIONS OF VERB AFFIXES MARKING MAJOR PARTICIPANTS IN EAST PAPUAN LANGUAGES}

\begin{tabular}{|c|c|c|}
\hline \multirow[t]{5}{*}{ New Britain } & Anêm & $s-V_{-}-$ \\
\hline & Ata & $\begin{array}{l}\mathrm{s}-\mathrm{V}-\mathrm{o} \\
\mathrm{V}-\mathrm{s} \text { (experientials) }\end{array}$ \\
\hline & Sulka & $s-\mathrm{V}$ \\
\hline & Baining & free pronouns only \\
\hline & Taulil & free pronouns only \\
\hline New Ireland & Kuot & $\begin{array}{l}o-V-s \\
\text { s-V-o } \\
o-s-V \\
o-V-s-V\end{array}$ \\
\hline \multirow[t]{4}{*}{ Bougainville } & Rotokas & V- (all suffixes, order unknown) \\
\hline & Nasioi & $\mathrm{V}-\mathrm{o}-\mathrm{s}$ \\
\hline & Koromira & V- (all suffixes, order unknown) \\
\hline & Motuna & $\mathrm{V}-\mathrm{o} / \mathrm{s}-\mathrm{s}$ \\
\hline \multirow[t]{4}{*}{ Solomons } & Bilua & free pronouns only \\
\hline & Touo (Baniata) & $\mathrm{V}-\mathrm{o}$ \\
\hline & Lavukaleve & $\begin{array}{l}0-s-V \\
s-V-o \\
o-V-s\end{array}$ \\
\hline & Savosavo & $\begin{array}{l}\mathrm{V}-\mathrm{o} \\
\mathrm{o}-\mathrm{V} \\
\mathrm{o}-\mathrm{V}-\mathrm{o}\end{array}$ \\
\hline Rossel & Yélî Dnye & free pronouns only \\
\hline $\begin{array}{l}\text { Reefs- } \\
\text { Santa Cruz }\end{array}$ & & $\begin{array}{l}V-s-c \\
s-V \\
s-V-s \text { (for 3PL only) }\end{array}$ \\
\hline
\end{tabular}


There are a number of areal similarities within each major island group. The Bougainville languages are characterized by their almost completely suffixing nature, whereas in all other islands, there are both prefixes and suffixes.

Anêm and Ata on New Britain share many similarities in their verbal morphology. Both languages have different suffixes marking object and one of a small number of verb classes. For both languages, subjects are marked by portmanteau suffixes, in one case marking subject and mood, and in the other subject and aspect. In both cases, verb classes themselves are determined in part semantically.

It is in the Central Solomon Islands that we see the most variation. On the surface, Touo (Baniata) appears to have been heavily influenced in its verb phrase structure by surrounding Oceanic languages, and Bilua only slightly less so. Lavukaleve and Savosavo, on the other hand, exhibit profoundly un-Oceanic features and show little sign of their close proximity over what has perhaps been an extremely long time.

5. DISCUSSION AND CONCLUSIONS. Perhaps the most striking fact that emerges from the preceding is the varied nature of the East Papuan languages. Our brief and-in places--sketchy typological survey has brought up great differences in linguistic type among these languages.

However, we can make some generalizations. Our initial questions had to do with distinguishing Papuan inheritance from Austronesian contact: whether it is possible to trace early pre-Austronesian Papuan features; and, related to this, whether it is possible to point to certain features as typically Papuan, or typical of the Papuan languages of this area. We are now in a position to make at least some tentative observations about these questions.

Certain features of East Papuan languages are most likely to have come as borrowings from their Austronesian neighbors. The inclusive/exclusive pronoun distinction (in the languages that have it) is a likely candidate, and the S V-o verb phrase structure in some languages is also suggestive of Austronesian contact. It is noteworthy, though, that not all East Papuan languages do have an inclusive/exclusive distinction, and many do not have an S V-o verb phrase structure. This speaks to a certain level of resistance to Austronesian loans in this area, despite the long time-depth of contact. The dual number category is virtually ubiquitous in East Papuan languages, and of note here is that it is an innovation in Oceanic languages. It is possible that these facts are causally related, although one would hesitate to speculate too far in this direction.

What is Papuan about the East Papuan languages? Although word order is one of the features that is easily changed by diffusion, it seems reasonable to state that $\mathrm{SOV}$, or more accurately V-final, order of the clause is typically Papuan, while Austronesian languages-at least the Oceanic ones-are typically object-final. The V-final order correlates highly with the use of postpositions and verbal suffixation for subject, and with the order Possessor-Possessed in possessive noun phrases.

While there are cases of Austronesian languages having adopted a V-final order due to Papuan contact, this has not happened in the area of East Papuan languages. 
There are only three areas where Papuan languages are not V-final, the Bird's Head, the Torricelli languages, and some of the East Papuan languages we reviewed in this paper. The majority of these languages have SVO order, use prepositions, and mark the subject by a verbal prefix, while still maintaining the Possessor-Possessed order. The major factor responsible for this typological shift from typical Papuan structure seems to be adjacency of Austronesian languages. In one case, Bilua, it seems that there was a recent shift to SVO, so that-despite the SVO constituent order-there are postpositions rather than prepositions.

The general V-initial order of Kuot-and its secondary role in languages of East New Britain and the Reefs-Santa Cruz islands-seems be a more isolated development that is certainly not typically Papuan, but cannot be easily traced to Austronesian influence either. As mentioned before, related to Papuan SOV are the typical Papuan strategies of information packaging, such as clause chaining and tail-head linkage. The former is impossible with a clause order that is not V-final, and thus is not found in any of the SVO or VSO languages. Tail-head linkage is less dependent on clausal order, and hence is easily transferred to other language types.

Constituent order of the NP is not easily identified with one stock of languages or the other. We have indicated that $\mathrm{N}+\mathrm{Adj}+\mathrm{Num}+\mathrm{Dem}$ is a rather common order for all Papuan groups, but that in the Sepik and the Highlands there are also languages with Dem + Adj $+\mathrm{N}$ order. For Oceanic languages, Lynch (I998: I 20) gives as a general rule the order Art $+\mathrm{N}+\mathrm{Adj}+\mathrm{Dem}$, but qualifies that the positions of numerals and quantifiers is more variable.

Another word-order feature that we suggest is typical Papuan, at least for some groups, is a clause-final position of the negative adverb. As discussed in Reesink (to appear), this seems to be an areal feature, in that it is present in the three areas where Papuan SVO languages occur, the Bird's Head peninsula of Irian Jaya, the Torricelli languages of northern Papua New Guinea, and the area of the East Papuan languages. It seems likely that sentence-final negation originated in a number of Papuan SOV languages, persevered in those that shifted their constituent order to SVO, and spread to adjacent Austronesian languages. Thus, the similarity between Papuan Anêm and Austronesian Lusi in New Britain is, in our opinion, not due to recent contact. The sentence-final negative must have an old history, which might, as a conjecture, represent a substrate influence in Austronesian languages such as MangapMbula in the Vitiaz Strait and Loniu of the Admiralty Islands.

Similarly, some morphological phenomena can be identified as Papuan, even if they can spread to Austronesian, as the distribution of gender distinctions in this area shows. The complexity of tense marking such as is present in various East Papuan languages is characteristic of mainland Papuan. There are no instances of multiple past or future tenses, such as that found in Rotokas, in Austronesian languages. Rather, the simple realis/irrealis distinction, as in Anêm and Ata, is possibly due to Austronesian influence.

Although none of these features can be taken as proof of a genetic relationship among the East Papuan languages, they are characteristic of Papuan languages in general, and thus make for some unity among the East Papuan languages, either as genetically inherited from one or more ancestral languages or the result of contact 
among these languages predating the arrival of the Austronesians. The Austronesian languages have left their imprint on the Papuan languages to different degrees. NPinitial articles have been adopted in languages scattered throughout the region, but especially in the Papuan languages of New Britain. Other languages have organized their possessive phrase on the Austronesian template. Virtually all have adopted the inclusive/exclusive opposition for first person plural, except the East New Britain languages, the South Bougainville family, and geographically isolated Yélî Dnye.

On another level, we can also make certain observations about smaller island groupings. Our paper concerns questions of typological similarities, not genetic relatedness, so we are not in a position to make (or contradict) claims of genetic relatedness, but nonetheless it is instructive to compare Ross's (2000) suggested genetic groups with our typological relationships. Ross tentatively suggests eight separate genetic groups (see figure I): Yele-West New Britain, Kuot, Kol, Sulka, East New Britain, South Bougainville, North Bougainville, and Central Solomons. In general, we find that typological similarities correlate with Ross's suggested groupings. In particular, the languages of Bougainville, which Ross groups into a North Bougainville family and an (unrelated) South Bougainville family, show great typological similarities. We do not observe great structural differences between the northern and southern Bougainville languages; but again, this says nothing about their genetic relationships.

Kuot stands on its own with respect to the languages of New Britain, as indeed with respect to all the other East Papuan languages. For Kol and Sulka, we do not have enough data on which to make any claims whatsoever.

Perhaps the most interesting of Ross's claims is the close relationship he posits between Anêm and Ata (the West New Britain family) on the one hand and Yélî Dnye on the other. We have not found any typological relationships between these two groups; Yélî Dnye is divergent from the other East Papuan languages in its verb phrase structure, the paradigmatic structure of its pronouns, and its basic syntactic patterns. Indeed, Henderson (I995:39) points to the polyfocal paradigmatic structure in Yélî Dnye as having a parallel in highland New Guinea languages.

The question arising from this is not why Yélî Dnye should be so different in its structural features from Anêm and Ata; difference is easily accounted for by great time depth and vast distance (in human transport terms) between these languages. The question, rather, is why Anêm and Ata should be so similar. Ata is much closer geographically to Sulka, Kol, Baining, Butam, and Taulil, but it is to the much more distant Anêm that it shows great similarities.

Their pronominal forms (discussed in Ross 2000 , with protoforms reconstructed) together with their verb structure show great similarity. Thurston (I982) suggests that Papuan languages of New Britain are the remnants of languages that once covered the whole island, possibly more Papuan languages than survive there today, and that the many Austronesian languages now intervening between the Papuan remnants have become heavily influenced by the original Papuan languages.

Thurston shows, via lexical reconstruction and oral history, that Anêm was previously spoken in the interior of New Britain, not on the coast as it is today; that it was 
spoken by a much larger number of people than it is today; and that these people were not seafaring people. This is important, because it shows that the relationship between Anêm and Ata is not one that could have been facilitated, in relatively recent times, by frequent sea-based communication (and note that Ata is spoken in the interior of New Britain as well). New Britain is a large island, and its rugged mountainous interior makes it unlikely that Ata and Anêm populations have been in direct contact for a very long time. We have no evidence of the pre-European history of the Ata people, but the close similarity between Anêm and Ata suggests a number of possible scenarios: for instance, that they have in fact been in contact until relatively recently, and thus one or both have recently moved away from an earlier close proximity; or that they are simply both very conservative languages, and thus represent a truer picture of pre-Austronesian Papuan languages than any of the other languages of the area. Chowning (I996, and further references cited therein) notes the archaeological evidence of frequent population movement in New Britain, caused in part by active volcanoes on the island. The prevailing archaeological picture and oral history from various groups on the island indicate that there has been frequent population movement as volcanoes made different areas uninhabitable. This suggests that the first scenario outlined above to account for why Anêm and Ata are so similar may be the correct one. More information on Sulka, Kol, Baining, and Taulil would be revealing for either possibility.

The Central Solomons languages also raise interesting questions with respect to Ross's (2000) claims of relationships between the East Papuan languages. These languages show great divergence from each other in their typological features, unlike the apparent similarities between their pronoun paradigms. Indeed, their verbal morphology, constituent order, and general structure betray few resemblances. In particular, Lavukaleve and Savosavo show the most promising non-Austronesian features, and they, together with Kuot, may be worth examining for ancient relationships.

\section{REFERENCES}

Blake, Barry. 1988. Redefining Pama-Nyungan: Towards the prehistory of Australian languages. In Aboriginal linguistics I, ed. by Nicholas Evans and Steve Johnson. I-90.

. I991. The significance of pronouns in the Australian languages. In Patterns of change, change of patterns, ed. by Philip Baldi. Berlin: Mouton de Gruyter. 219-234. .

Chowning, Ann. 1996. Relations among languages of West New Britain: An assessment of recent theories and evidence. In Studies in languages of New Britain and New Ireland, ed. by Malcolm Ross, 7-62. Series C-135. Canberra: Pacific Linguistics.

Cysouw, Michael. 200I. The paradigmatic structure of person marking. Ph.D. thesis, Katholieke Universiteit, Nijmegen.

Firchow, Irwin B. 1987. Form and function of Rotokas words. Language and Linguistics in Melanesia I 5:5-I I I.

Foley, William. 1986. The Papuan languages of New Guinea. Cambridge: Cambridge University Press.

- 1998. Toward understanding Papuan languages. In Perspectives on the Bird's Head, ed. by Jelle Miedema, Cecilia Odé, and Rien Dam, 503-51 8. Amsterdam: Rodopi. 
Greenberg, Joseph H. 197I. The Indo-Pacific hypothesis. In Current trends in linguistics 8: Linguistics in Oceania, ed. by Thomas Sebeok, 807-871. The Hague: Mouton.

Hashimoto, Kazuo. n.d. Ata grammar essentials. Summer Institute of Linguistics.

Hawkins, John, and Anne Cutler. 1988. Psycholinguistic factors in morphological asymmetry. In Explaining language universals, ed. by John Hawkins, 280-3I 7. Oxford: Basil Blackwell.

Henderson, James. I 995. Phonology and grammar of Yele, Papua New Guinea. Series BI I 2. Canberra: Pacific Linguistics.

Hurd, Conrad, and Phyllis Hurd. 1970. Nasioi verbs. Oceanic Linguistics 9:37-78.

Johnston, Raymond. 1980. Language, communication, and development in New Britain. Ukarumpa: Summer Institute of Linguistics.

Kayser, Manfred, Silke Brauer, Gunter Weiss, Peter Underhill, Lutz Rower, Wulf Schiefenhövel, and Mark Stoneking. 2000. Melanesian origin of Polynesian Y chromosomes. Current Biology I0: I 237-I 246.

Kirch, Patrick. 1997. The Lapita peoples. London: Blackwell.

Laufer, Carl. I 950. Die Taulil und ihre Sprache. Anthropos 45:627-640.

- I959. Otto Futscher M.S.C., Taulil-Grammatik und naturwissenschaftliche Sammerlarbeiten aus Neubrittanien (Südsee). Anthropos 54:2 I 3-2 I 7.

Layock, Donald, and Masa Onishi. n.d. Laycock's Elementary Buin grammar edited by Onishi. Unpublished ms.

Lincoln, Peter. 1978. Reef-Santa Cruz as Austronesian. In Second International Conference on Austronesian Linguistics: Proceedings, ed. by Stephen Wurm and Lois Carrington, 929-967. Series C-6I. Canberra: Pacific Linguistics.

Lynch, John. 1998. Pacific languages: An introduction. Honolulu: University of Hawai'i Press.

Mosel, Ulrike. I999. Towards a typology of negation in Oceanic languages. In Negation in Oceanic Languages, ed. by Even Hovdhagen and Ulrike Mosel, I-I 9. Lincom Europa.

Obata, Kazuko. 2000. A grammar of Bilua, a Papuan language of the Solomon Islands. Ph.D. thesis, Department of Linguistics, Faculty of Arts, Australian National University.

Onishi, Masayuki. I994: A grammar of Motuna (Bougainville, PNG). Ph.D. thesis, Department of Linguistics, Faculty of Arts, Australian National University.

Parker, Jim, and Diana Parker. I977. Baining grammar essentials, pt. I (stems, words, phrases). Unpublished ms., SIL.

Rausch, J. I9I2. Die Sprache von Südost-Bougainville, Deutsche Salomonsinseln. Anthropos 7:105-I 34, 585-616, 964-994, I056-1057.

Reesink, Ger. 1998. The Bird's Head as Sprachbund. In Perspectives on the Bird's Head, ed. by Jelle Miedema, Cecilia Odé, and Rien Dam, 603-642. Amsterdam: Rodopi.

- 2000. West Papuan languages: Roots and development. Paper given at Conference on Papuan Pasts, Canberra, November 27-30.

- To appear. Clause-final negation: Structure and interpretation. In Functions of Language, ed. by Kristin Davidse, William McGregor, and Anne-Marie SimonVenderbergen. Amsterdam: John Benjamins.

Ross, Malcolm. 1988. Proto Oceanic and the Austronesian languages of Western Melanesia. Series C-98. Canberra: Pacific Linguistics.

2000. Pronouns as markers of genetic stocks in non-Austronesian languages of New Guinea and Island Melanesia and Eastern Indonesia. In Papuan languages and the Trans New Guinea Phylum, ed. by Andrew Pawley, Malcolm Ross, and Meredith Osmond. Unpublished ms. Department of Linguistics, Research School of Pacific and Asian Studies, Australian National University.

Spriggs, Matthew. I997. The Island Melanesians. London: Blackwell. 
Terrill, Angela. 1999. Lavukaleve, a Papuan language of the Solomon Islands. Ph.D. thesis, Department of Linguistics, Research School of Pacific and Asian Studies, Australian National University.

2002. Systems of nominal classification in East Papuan languages. Oceanic Linguistics 4I:63-88 [this issue].

Terrill, Angela, and Michael Dunn. Forthcoming. Orthographic design in the Solomon Islands: The social, historical, and linguistic situation of Touo (Baniata). To appear in Written language and literacy.

Tharp, Doug. 1996. Sulka grammar essentials. In Two non-Austronesian grammars from the islands, ed. by John M. Clifton, 77-I79. Ukanumpa: Summer Institute of Linguistics.

Thurston, William. 1982. A comparative study of Anêm and Lusi. Series B-83. Canberra: Pacific Linguistics.

Todd, Evelyn. 1975. The Solomon language family. In New Guinea area languages and language study, vol. I, Papuan languages and the New Guinea linguistic scene, ed. by Stephen Wurm, 805-836. Series C-38. Canberra: Pacific Linguistics.

Tryon, Darrell. 1994. Language contact and contact-induced language change in the Eastern Outer Islands, Solomon Islands. In Language contact and change in the Austronesian world, ed. by Tom Dutton and Darrell Tryon, 6 I I-648. Berlin: Mouton de Gruyter.

Wurm, Stephen. I969. The linguistic situation in the Reef and Santa Cruz Islands. Papers in Linguistics of Melanesia No. 2:47-105. Series A-2 I. Canberra: Pacific Linguistics.

- 1975. The East Papuan Phylum in general. In Papuan languages and the New Guinea linguistic scene, ed. by Stephen Wurm, 783-803. Series C-38. Canberra: Pacific Linguistics.

- 1976. The Reef Island/Santa Cruz family. In New Guinea area languages and language study, vol. 2: Austronesian languages, ed. by Stephen Wurm, 637-764. Series C-39. Canberra: Pacific Linguistics.

- 198I. Notes on nominal classification in Äiwo, Reef Islands, Solomon Islands. In Linguistics across continents, ed. by Andrew Gonzalez and David Thomas, I 23-1 42. Manila: Summer Institute of Linguistics and Linguistic Society of the Philippines.

- 1982a. Austronesian and Non-Austronesian (Papuan) languages in contact: Some notes. In Gava': Studies in Austronesian languages and cultures dedicated to Hans Kähler, ed. by Rainer Carle, Martine Heinschke, Peter Pink, Christel Rost, and Karen Stadtlander, 87-I09. Berlin: Reimer Verlag.

- 1982b. Papuan languages of Oceania. Tübingen: Narr.

. I992a. Some features of the verb complex in Northern Santa Cruzan, Solomon Islands. In The language game: Papers in memory of Donald C. Laycock, ed. by Malcolm Ross, Darrell Tryon, and Tom Dutton, 527-552. Series C-I Io. Canberra: Pacific Linguistics.

- 1992b. Change of language structure and typology in a Pacific language as a result of culture change. In Culture change, language change: Case studies from Melanesia, ed. by Tom Dutton, I 41-157. Series C-I 20. Canberra: Pacific Linguistics.

\author{
Michael Dunn \\ Max Planck Institute for \\ Psycholinguistics \\ P. O. Box 3 IO \\ 6500 AH Nijmegen \\ The Netherlands \\ michael.dunn@mpi.nl
}

Ger Reesink
Leiden University
Centre for Linguistics
P. O. Box 95I 5
2300 RA Leiden
The Netherlands
g.p.reesink@let.leidenuniv.nl

\author{
Angela Terrill \\ Max Planck Institute for \\ Evolutionary Anthropology \\ Inselstrasse 22 \\ 04103 Leipzig \\ Germany \\ angela.terrill@mpi.nl
}

